\title{
A Lost Medieval Manuscript from North Wales: Hengwrt 33, The Hanesyn Hên
}

\author{
BEN GUY \\ Cambridge University
}

In 1658, William Maurice made a catalogue of the most important manuscripts in the library of Robert Vaughan of Hengwrt, in which 158 items were listed. ${ }^{1}$ Many copies of Maurice's catalogue exist, deriving from two variant versions, best represented respectively by the copies in Aberystwyth, National Library of Wales [= NLW], Wynnstay 10, written by Maurice's amanuenses in 1671 and annotated by Maurice himself, and in NLW Peniarth 119, written by Edward Lhwyd and his collaborators around $1700 .^{2}$ In 1843 , Aneirin Owen created a list of those manuscripts in Maurice's catalogue which he was able to find still present in the Hengwrt (later Peniarth) collection. ${ }^{3}$ W. W. E. Wynne later responded by publishing a list, based on Maurice's catalogue, of the manuscripts which Owen believed to be missing, some of which Wynne was able to identify as extant. ${ }^{4}$ Among the manuscripts remaining unidentified was item 33, the manuscript which Edward Lhwyd had called the 'Hanesyn Hên'. ${ }^{5}$ The contents list provided by Maurice in his catalogue shows that this manuscript was of considerable interest. ${ }^{6}$ The entries for Hengwrt 33 in both Wynnstay 10 and Peniarth 119 are identical in all significant respects. These lists are supplemented by a briefer list compiled by Lhwyd and included elsewhere in Peniarth 119 as part of a document entitled 'A Catalogue of some MSS. in Hengwrt study $\mathrm{A}^{\mathrm{o}} 1696{ }^{\prime}{ }^{7}$ In table 1 below, the latter's entry on Hengwrt 33 is printed in parallel with the text from Wynnstay 10. The contents list of Hengwrt 33 published in Lhwyd's Archaeologia Britannica is evidently a conflation of Maurice's list and the list in Lhwyd's 1696 catalogue, a circumstance which led to the accidental inclusion of the vernacular chronicle $O$ Oes Gwrtheyrn at two different points. ${ }^{8}$

${ }^{1}$ Daniel Huws, Medieval Welsh Manuscripts [= $M W M]$ (Cardiff and Aberystwyth, 2000), pp. 261 and 294.

2 For a list of manuscripts containing the catalogue, see Handlist of Manuscripts in the National Library of Wales (Aberystwyth, 1940-), i, pp. xvi-xx.

3 Aneirin Owen, 'Catalogue of Welsh Manuscripts, etc. in North Wales, No. II', Transactions of the Cymmrodorion or the Metropolitan Cambrian Institution, 2.4 (1843), 400-18 (403-16).

4 W. W. E. Wynne, 'MSS. missing from the Hengwrt Collection', Archaeologia Cambrensis, 4th ser., 2 (1871), 129-37.

5 Wynne, 'MSS.', 130; Edward Lluyd, Archaeologia Britannica: An Account of the Languages, Histories, and Customs of the Original Inhabitants of Great Britain. Vol. 1: Glossary (Oxford, 1707), p. 256. The earliest use of the title 'Hanesyn Hên' that I have been able to find appears in Lhwyd's copy of Maurice's catalogue in Peniarth 119, p. 79.

6 Maurice's description of the contents of Hengwrt 33 has been printed twice before, once in the Cambrian Register for 1818, taken from an unknown source, and once by A. O. H. Jarman, taken from Wynnstay 10, as communicated to him by E. D. Jones: 'A Catalogue of the Curious and Valuable MSS. in Hengwrt Library, A. D. 1658', The Cambrian Register, 3 (1818), 278-313 (281); A. O. H. Jarman, Ymddiddan Myrddin a Thaliesin (o Lyfr Du Caerfyrddin) (Cardiff, 1951), p. 20. On the Cambrian Register catalogue, see Handlist, i, p. xx. Wynne translated Maurice's entry into English in 'MSS.', 130.

7 Peniarth 119, pp. 101-3; the contents of Hengwrt 33 are listed on p. 103. Cf. Handlist, i, p. xxi.

8 Lhuyd, Archaeologia Britannica, p. 256. 
Table 1. The Contents of Hengwrt 33

Wynnstay 10, ff. 246r-246 , item 33 (1671)

Peniarth 119, p. 103, item 63 (c.1700)

Llyfr hên Tra rhagorol

yn yr hwn $n$ y mae yn gyntaf:

Achau Seint Ynys Prydain;

Ancient Genealogies

2: Plant Brychann, a llawer o bethau Achawl (neu Geneologiol)

Item: Chronologieth yn dechreu Oes

Gwrtheurn Gwrtheneu; ${ }^{9}$

Item: Llyfr Bonedd;

Item: Englynion Duad;

Item: Anrheg Vrrien o waith Taliesyn;

Marwnad Iago mab Beli, [o waith Beli]

o 'waith Taliesun;

Item. Ach Llewelyn ab Ierwerth Drwyndwnn;

Item: Duad;

Item. Henweu Brenhinoedd Ynys Prydain;

Item: Llyfr Theophrastus am Neithiorau;

Item: Chronicl byrr yn dechreu yn Oes

Arthur, pan lâs Arthur;

Audyl a gant Adaf Vrâs

Auret Urien: Taliesyn ai cant

Marunat Iago ap Lledi, o waith Taliesyn

Acheu Llewelyn ap Iorwerth

Chronicon o oes Gorthyrn Gortheneu hyd y Nordmyn

O Gad Gamlan i Ed.2.

Henweu y Brenhined o Eneas Ysgwythwyn i Gadwaladyr Vendigeit

Item: Gwaith Merddyn yw Barchell;

Llyfr 'gwedy ei gaeadu yn odieth ymgeledus

yn Llyndain y gan Rob: Va:

In octavo, i Fodf: o Dêw

membr. $4^{\text {to }}$

Hengwrt 33 was evidently a medieval manuscript written on vellum. The contents included genealogy (both sacred and secular), poetry (englynion and awdlau), chronicles and Theophrastus's tract against marriage. Although the manuscript is occasionally mentioned in scholarship, it deserves a much fuller treatment than it has yet received, not least because copies of a number of the items that it once contained can be identified in various extant manuscripts of later date. The present examination attempts to determine exactly how many extant manuscripts derive from or are closely related to the lost Hengwrt 33. On the basis of the evidence of these derivatives and relatives, it is suggested that Hengwrt 33 was written in the first half of the fourteenth century, perhaps in Valle Crucis Abbey, and that much of its contents derives from Aberconwy Abbey. Following the article is an appendix, in which is edited a series of texts derived from the lost manuscript. 


\section{Genealogy}

Surviving manuscripts that can be identified as relatives of Hengwrt 33 contain various combinations of genealogy, chronicle and poetry. Here I treat the genealogical manuscripts first, since they are the most numerous and informative, before continuing to consider the manuscripts containing poetry and chronicles.

Arguably the most important surviving transcript of a section of Hengwrt 33 is that of John Jones of Gellilyfdy. ${ }^{10}$ In 1640, while in the Fleet Street prison in London, John Jones transcribed the genealogical sections of some of the earliest manuscripts in Robert Vaughan's collection at Hengwrt. This set of transcripts is preserved as Cardiff Central Library 3.77. ${ }^{11}$ Peter Bartrum identified the manuscripts transcribed by John Jones into Cardiff 3.77: pages 23-31 contain a transcript of Bonedd y Saint from NLW Peniarth 16, part vi ${ }^{12}$ (s. xiii ${ }^{2}$; a fragment of the Dingestow manuscript); pages 101-10 were transcribed

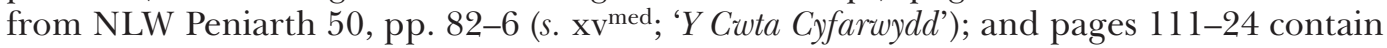
transcriptions of Bonedd y Saint, Ach Arthur and Ach Owain Tudur from NLW Peniarth 27, part ii $(s . \mathrm{xv} / \mathrm{xvi}) .{ }^{13}$ Egerton Phillimore was the first to realise that other parts of Cardiff 3.77 had been copied from the lost Hengwrt 33. ${ }^{14}$ Phillimore's views on this matter are scattered among many incidental references, but can be pieced together easily enough. ${ }^{15}$ He thought that Hengwrt 33 was a manuscript written in the thirteenth or fourteenth

9 The relevant positioning of Chronologieth yn dechreu Oes Gwrtheurn Gwrtheneu and Henweu Brenhinoedd Ynys Prydain is at variance in the two lists. As is discussed below (p. 77), Peniarth 119 is likely to preserve the order of Hengwrt 33.

${ }^{10}$ For John Jones and Welsh genealogy, see Nesta Lloyd, 'A History of Welsh Scholarship in the first half of the Seventeenth Century, with special reference to the Writings of John Jones, Gellilyfdy', 2 vols (unpublished DPhil thesis, University of Oxford, 1970), i, pp. $151-7$.

11 See J. Gwenogvryn Evans, Report on Manuscripts in the Welsh Language [= RMWL], 2 vols (London, 1898-1910), II.i, pp. 213-14. Gwenogvryn Evans labelled the manuscript 'Cardiff MS 25'.

12 Often called part 'iv', but see Daniel Huws, $A$ Repertory of Welsh Manuscripts and Scribes (forthcoming), s. 'Peniarth 16 '.

13 P. C. Bartrum, Early Welsh Genealogical Tracts [= EWGT] (Cardiff, 1966), p. 76. For the dates of these manuscripts, see $M W M$ 58,61 and 63. For Peniarth $16 \mathrm{vi}$ as a fragment of the Dingestow manuscript (NLW 5266B), see Rachel Bromwich, Trioedd Ynys Prydein: The Triads of the Island of Britain (3rd edn, Cardiff, 2006), p. xvi; Paul Russell, 'What did Medieval Welsh Scribes do? The Scribe of the Dingestow Court MS', Cambrian Medieval Celtic Studies, 37 (1999), 79-96 (925). The versions of Bonedd y Saint contained in Peniarth 16vi and Peniarth 27ii are, respectively, versions $\mathrm{A}$ and $\mathrm{F}$, which have each been published separately: version A in S. Baring-Gould and John Fisher, The Lives of the British Saints, 4 vols (London, 1907-13), iv, pp. 369-71, and version F in A. W. WadeEvans, 'Bonedd y Saint, F; Bonedd y Saint, G; Bonedd y Saint, H', Revue Celtique, 50 (1933), 363-87 (363-7).
Versions of sections of Ach Arthur and Ach Owain Tudur have been published by Bartrum in EWGT 93-4 and 121.

14 Phillimore's own transcript of Cardiff 3.77 is preserved in the National Library of Wales: Egerton Phillimore Papers, N3/3: 'Pedigrees of British Kings and Saints'. The transcript was made in March and April 1889.

${ }^{15}$ For the work of Egerton Phillimore, see Ben Guy, 'Egerton Phillimore (1856-1937) and the Study of Welsh Historical Texts', Transactions of the Honourable Society of Cymmrodorion [= THSC], 21 (2015), 36-50. Phillimore's references to Hengwrt 33 include the following: Phillimore apud H. F. J. Vaughan, 'Welsh Pedigrees', $Y$ Cymmrodor $[=C y], 10$ (1889), 72-156 (85, n. 9, 91, n. 8, and 152-3, n. 8); 'Errata, \&c., in vol. ix', Cy 10 (1889), 246-8 (248); 'Notes on Place-Names in English Maelor', Bye-Gones relating to Wales and Border Counties, 2nd ser., 1 (1889-90), 478-85 and 532-7 (480, n. 2, 484 and 535); Phillimore apud J. E. Lloyd, 'Welsh Place-Names: A Study of Some Common Name Elements', Cy 11 (1890-91), 15-60 (50); Phillimore apud J. W. Willis-Bund, 'The True Objects of Welsh Archæology', Cy 11 (1890-91), 103-32 (126); 'The Publication of Welsh Historical Records', Cy 11 (189091), 133-75 (135, n. 4); Phillimore apud John Rhŷs, 'The Irish Invasions of Wales and Dumnonia', Archaeologia Cambrensis, 5th ser., 9 (1892), 56-73 (635); 'homo planus and Leprosy in Wales', Archaeologia Cambrensis, 6th ser., 20 (1920), 224-50 (246, n. 20); Phillimore apud The Description of Penbrokshire [sic] by George Owen of Henllys, Lord of Kemes, ed. Henry Owen, Cymmrodorion Record Series, 1, 2 vols in 4 parts (London, 1892-1936), I.i, p. 201, n. 1; II.i, pp. 277-8, n. 1; II.ii, p. 625 . 
century, and that its genealogical contents had been copied twice into Cardiff 3.77, within pages $1-100 .{ }^{16}$ The rationale behind the assumption that John Jones was copying directly from Hengwrt 33 is based on our knowledge of what would have been available to Jones in the library of Robert Vaughan in 1640. On page 22 of Cardiff 3.77, at the end of a section that Phillimore thought had been copied from Hengwrt 33, John Jones says the following about his source.

Ag fal hynn y teṛfyna y lyf̣̣ hụn yr hynn a ysgṛifennais if, aḷan o lyf̣̣ byçan o femrụn (ợ eiḍo yg kar Robeṛt 6yçan, or Hengụ̣t yn ymyl Dolgele yn sir Feirionnyḍ) (yr hụn a ysgrifennessid yg kyḷ̣ :400: mḷneḍ kyn no hynny). Y :17: dyḍ o fis medi :1640: yn y ffḷtut, yg ḳaer luḍ.

And like this finishes this book which I wrote out of a little book of vellum (belonging to my friend Robert Vaughan of Hengwrt near Dolgellau in Merionethshire) (which had been written about 400 years earlier). The 17th day of September 1640 in the Fleet in London.

The manuscript copied by John Jones into the beginning of Cardiff 3.77 was evidently a vellum manuscript belonging to Robert Vaughan, and, judging by what was copied, the only vellum manuscript in Robert Vaughan's possession that would have included the relevant contents was Hengwrt 33, as can be deduced from William Maurice's catalogue.

Phillimore's views on this matter received only occasional notice in succeeding years until they were explored further by Peter Bartrum. ${ }^{17}$ Bartrum's primary contributions were the delimitation of exactly which part of Cardiff 3.77 had been copied from Hengwrt 33 and the identification of two further copies of the manuscript. ${ }^{18}$ He argued that only pages 1-22 of Cardiff 3.77, the section immediately preceding the colophon quoted above, had been copied from Hengwrt 33. Pages 32-100, on the other hand, which Phillimore thought contained a 'second copy' of the material in Hengwrt 33, were actually copied from another lost medieval manuscript, which Bartrum named ' $\mathrm{Y}$ '. ${ }^{19}$ Bartrum suggested that at least parts of Y 'came from Hengwrt 141', a Hengwrt manuscript no longer extant, but this is very unlikely. All that is known of Hengwrt 141 is that it was an 'old book of pedigrees patched by John Jones', and that it featured the title 'Gynwyd Cevyn Blaidd Cynllaith' in a prominent position. ${ }^{20}$ The latter is a subtitle that appears in Gutun Owain's genealogical compilation in Manchester, John Rylands Library, Welsh 1, written in 1497 in Gutun Owain's own hand, which reads, at the top of the current folio $12^{\mathrm{r}}$, kymwd kefn blaidd kynllaith. Since there is no evidence that Robert Vaughan or John Jones ever saw Rylands Welsh 1, I suggest that Hengwrt 141 derived from that manuscript, which was much copied in the sixteenth century. ${ }^{21}$

16 Bartrum also summarises Phillimore's views in 'Bonedd yr Arwyr', Bulletin of the Board of Celtic Studies [= BBCS], 18 (1958-60), 229-52 (231).

17 For example, A. O. H. Jarman referred to some of Phillimore's work on Hengwrt 33 in 1951, while Francis Jones mentioned Hanesyn Hên as an 'early' and 'reputable' Welsh genealogical manuscript in an essay written in 1952: Jarman, Ymddiddan, pp. 19-21; Francis Jones, 'Welsh Pedigrees', in Burke's Genealogical and Heraldic History of the Landed Gentry, ed. L. G. Pine (17th edn, London, 1952), pp. lxixlxxvi (p. lxxii). A few years earlier, Francis Jones had urged the publication of the Hanesyn Hên genealogies in Cardiff 3.77, though he misused the label 'Hanesyn $H e ̂ n '$ as a reference to the Cardiff manuscript itself rather than its exemplar, Hengwrt 33: Francis Jones, 'An Approach to Welsh Genealogy', THSC (1948), 303-466 (345-6).

18 Set forth in 'Bonedd yr Arwyr', 230-1; 'Achau Brenhinoedd a Thywysogion Cymru', BBCS 19 (1961-2), 201-25 (201-4); EWGT 75-8.

19 Phillimore, 'Notes', 480, n. 2; EWGT 76.

20 Wynne, 'MSS.', 135.

21 For Rylands Welsh 1 and its derivatives, see P. C. 
Bartrum argued that two other extant manuscripts contain copies of the genealogical sections of Hengwrt 33: NLW Llanstephan 28, written by Gutun Owain, seemingly in 1456, and NLW Peniarth 182, written by Huw Pennant between 1509 and $1513 .^{22}$ Bartrum realised that the genealogical material in these two manuscripts correlates with the material in Cardiff 3.77, pages 1-22, and with the contents list of Hengwrt 33. ${ }^{23}$ Most persuasively, all three manuscripts contain similarly corrupt texts of Plant Brychan. Peniarth 182 contains the opening section and the concluding triad, but nothing else. Llanstephan 28 contains the same opening section, followed additionally by Brychan's son Cynog, and then begins its list of Brychan's other children half way through the list of daughters, with Kyngaer verch Vrychan ${ }^{24}$ In Cardiff 3.77, John Jones begins with Keyngar ferc Vryçan, prior to which he left a six-line gap followed by the words gwreig Tudaul Pefyr, the ending of the item that usually precedes Ceingar in other texts of Plant Brychan. The six-line gap probably indicates either that John Jones' exemplar was damaged at this point, or that he realised that a significant portion of Plant Brychan's text was missing. The same factor must lie behind the state of Plant Brychan in Llanstephan 28 and Peniarth 182. It is likely that the latter two manuscripts derive their genealogical texts, directly or indirectly, from Hengwrt 33.

Three other Plant Brychan manuscripts shed some light on what may have befallen the missing text in Hengwrt 33. ${ }^{25}$ All three of them are linked to a confined area of Radnorshire: NLW Peniarth 137, part iii, written by one John ap Rhys of Llanfihangel Nant Melan sometime in the second half of the sixteenth century; NLW Peniarth 183, part ii, written by William Dyfi in 1586, a manuscript which received additions from residents of Glasgwm and Pilleth in Radnorshire during the seventeenth century; and London, British Library [= BL], Harley 4181, written by Hugh Thomas, who in 1710 copied into folios $25^{\mathrm{v}}-27^{\mathrm{r}}$ texts of Bonedd y Saint and Plant Brychan 'taken out of an old Welsh manuscrip [sic] of Mr John Lewis of Lhuynweney in Radnorshire wrote about the time of Queen Elizabeth'. ${ }^{26}$ Like John ap Rees, John Lewis (d. 1615/16) became a resident of Llanfihangel Nant Melan parish around 1596, though he had maintained landed interests in the area for some time before. ${ }^{27}$ The copies of Plant Brychan in these three manuscripts are very similar. The copies in Peniarth $183 \mathrm{ii}$ and Harley 4181 are particularly close. ${ }^{28}$ It is tempting to suggest that the common exemplar of the three had taken

Bartrum, 'Further Notes on Welsh Genealogical Manuscripts', THSC (1976), 102-18 (104-6).

22 The significance of the 1456 date for Llanstephan 28, found in two rubrics in the manuscript, has been disputed: Thomas Roberts, 'Llawysgrifau Gutun Owain, a thymor ei oes', BBCS 15 (1952-4), 99-109 (101-5); cf. G. J. Williams and E. J. Jones, Gramadegau'r Penceirddiaid (Cardiff, 1934), p. xlvi; L'œuvre poétique de Gutun Owain, ed. E. Bachellery (Paris, 1950-51), pp. 11-12. The matter has yet to be resolved conclusively.

23 For a table comparing their contents, see Bartrum, 'Achau', 204.

24 Llanstephan 28's text of Plant Brychan is printed in A. W. Wade-Evans, 'Bonedd y Saint, E', Archaeologia Cambrensis, 86 (1931), 158-75 (174).

25 The following draws on a full study of all the manuscripts containing Plant Brychan, which I intend to publish elsewhere.
26 For Peniarth 137, see $R M W L$ i, pp. 861-7. For Peniarth 183, see $R M W L$ i, pp. 1007-8; Annalee C. Rejhon, Cân Rolant: The Medieval Welsh Version of the Song of Roland (Berkeley, 1984), pp. 8-10. For Hugh Thomas, see Francis Jones, 'Hugh Thomas, Deputy Herald', THSC (1961), 45-71. The texts from Harley 4181 are edited in W. J. Rees, Lives of the Cambro British Saints (Llandovery, 1853), pp. 269-71.

27 Francis G. Payne, 'John Lewis, Llynwene, Historian and Antiquary', The Radnorshire Society Transactions, 30 (1960), 4-16 (7-9); cf. Egerton Phillimore, 'A Fragment from Hengwrt MS. No. 202', Cy 7 (1886), 89-154 (106, n. 2).

28 The kinship between the two manuscripts was noted by Bartrum: 'Late Additions to "Bonedd y Saint”, THSC (1959), 76-98 (81). Peniarth 183ii also contains a copy of Achau'r saint, which in Harley 4181 has been combined with Bonedd y Saint and Plant Brychan. For Achau'r Saint, see EWGT 68-71 and A. W. 
up residence in the vicinity of Llanfihangel Nant Melan in the second half of the sixteenth century. ${ }^{29}$ I call this common exemplar ' $\Lambda$ '.

What has all this to do with Hengwrt 33? The text of Plant Brychan found in these three manuscripts shares some peculiarities with the known derivatives of Hengwrt 33. For example, Brychan's ancestor Tathal appears in Peniarth 182 and Llanstephan 28 as Tuthal and in the Radnorshire manuscripts as Tuthal or Tythal, and the name of the daughter of Brychan usually called Ceindreg is spelled with an extra $e$ between the $d$ and $r$ in the Radnorshire manuscripts, Cardiff 3.77 and NLW 21001Bii, another derivative of Hengwrt 33 discussed below. $\Lambda$ cannot, however, derive from Hengwrt 33. Both Peniarth 137iii and Peniarth 183 ii contain texts of Bonedd y Saint, which, while very similar to the copies in Peniarth 182 and Llanstephan 28, contain features of Bonedd y Saint's archetype which have been altered in the latter two manuscripts, and which must also have been altered in Hengwrt 33. ${ }^{30} \Lambda$ must instead have been a sister copy of Hengwrt 33, or at least derived from such a sister copy. This makes $\Lambda$ 's arrangement of Plant Brychan all the more interesting. The three Radnorshire texts of Plant Brychan all begin with the introductory section on Brychan. Following this, Peniarth 137iii and Peniarth 183ii skip down to Ceingar, just like the copies of Hengwrt 33. Harley 4181 skips a little further still, to Gwawrddydd, because corrupt versions of the items on Ceingar and the following sister Golau have been moved to the end of the list instead. ${ }^{31}$ Unlike in the Hengwrt 33 copies, however, the intervening text has not completely disappeared. In the Radnorshire manuscripts, the missing daughters prior to Ceingar have been moved as a block to the end of the list of daughters. The missing sons are found only in Peniarth 137iii, but there they have become separated from the rest of Plant Brychan by the intervening text of Bonedd y Saint (cf. table 3 below). One cannot help but wonder if the common exemplar of Hengwrt 33 and $\Lambda$ had become unbound at this point. Perhaps at one stage loose leaves containing the relevant portions of text were arranged out of order, leading to the state of $\Lambda$, whilst at another stage the loose leaves had been lost, leading to the state of Hengwrt 33. This idea is speculative, but it cannot simply be a coincidence that the closely related copies of Plant Brychan in Hengwrt 33 and $\Lambda$ both jumped straight from Brychan to Ceingar.

There are two further manuscripts that would appear to contain genealogical texts derived from Hengwrt 33, each of which can tell us something new about the latter. One is NLW $21001 \mathrm{~B}$, a composite manuscript containing transcripts made for Edward Lhwyd. The second part of this manuscript is a transcript made in 1701 of a lost manuscript of William Salesbury (c.1520-c.1584), as is made clear on folio $180^{\mathrm{r}}$ :

Wade-Evans, 'Achau'r Saint, A, Achau'r Saint, B', Études Celtiques, 1 (1936), 281-91.

29 The manuscript may well, at some point, have been owned by John Lewis of Llynwene, a prominent collector of manuscripts: Payne, 'John Lewis', 15; Graham C. G. Thomas, 'From Manuscript to Print: I. Manuscript', in A Guide to Welsh Literature c.1530-1700, Volume III, ed. R. Geraint Gruffydd (Cardiff, 1997), pp. 241-62 (243). However, Payne's statement that Lewis owned Peniarth 137, including the portion by John ap Rhys of Llanfihangel Nant Melan, is misleading; Lewis owned part $\mathrm{i}$ of the manuscript, the former Hengwrt 251, which was copied by John Jones of Gellilyfdy into NLW 3041B (Mostyn 133), but there is no evidence that he owned part ii, the former Hengwrt 368, which was not bound with Hengwrt 251 until after the two manuscripts were catalogued separately by William Maurice in 1658.

30 The relevant idiosyncrasies of the texts of Bonedd y Saint in Peniarth 182 and Llanstephan 28 are the lack of Pedr's pedigree and the appearance of Llawfrodedd's epithet 'Farfog' as 'Farchog': cf. EWGT 55 and 62 ( $\$ 4$ and 54). My knowledge of the textual tradition of Bonedd y Saint is to a large extent indebted to Barry Lewis, to whom I am immensely grateful for his time and assistance in tackling these matters.

31 See the text in Rees, Lives, p. 271, \$60. 
Adskriv o lyvyr ym medhiant $\mathrm{M}^{\mathrm{rs}}$ Wyn o vod ysgelhan A.d. 1701. yr hwn a sgrivennase (hyd yr wi yn i vedhwl*) Wil ${ }^{m}$ Salsbri o Lan Rwst ynghylch amser y vrenhines Elsbeth.

A transcript from a book in the possession of Mrs Wyn of Bodysgallen A.D. 1701, which William Salesbury of Llanrwst had written (so I think) around the time of Queen Elizabeth.

The former existence of William Salesbury's manuscript has been recognised for some time thanks to various references to it by Edward Lhwyd and others, but the survival of a full transcript was not appreciated before B. G. Owens brought NLW 21001B to the attention of Peter Bartrum, no later than 1976. ${ }^{32}$ Among the contents of NLW 21001Bii are texts of Plant Brychan and the material named by Bartrum 'Bonedd yr Arwyr' which are very close to the texts in Cardiff 3.77, Llanstephan 28 and Peniarth 182. Most persuasively, the version of Plant Brychan preserved in NLW 21001Bii begins with Kynger verch Bryc'han, just like Cardiff 3.77 and Llanstephan 28.

The particular importance of NLW 21001Bii lies in the textual innovations that it shares with Llanstephan 28. For example, both of them omit Aneirin from the list of the children of Caw of Twrcelyn; both omit Tryderan, Meirchion and Uchno from the list of the children of Egri of Talybolion; and both omit to mention Elidir Lydanwyn as son of Meirchion ap Gorwst. However, individual errors in Llanstephan 28 show that William Salesbury cannot have copied his text directly from that manuscript. These features suggest that neither Llanstephan 28 nor NLW 21001Bii derive directly from Hengwrt 33; instead, both manuscripts derive from the same lost intermediary manuscript, which itself derived from Hengwrt 33.

The other new witness to the genealogical contents of Hengwrt 33 is Cardiff Central Library 2.108. This manuscript contains a single page $\left(33^{\mathrm{r}}\right)$ of Bonedd y Saint transcribed from Hengwrt 33, as may be concluded from the title at the top of the page:

Ex codice M[anu]s[crip]to perantiquo Membr[ana] dicto Hanesyn Hên.

From a very old vellum manuscript codex called Hanesyn Hên.

The significance of the transcript lies, however, in the identity of the scribe. Cardiff 2.108 was written by Richard Thomas (d. 1780), as stated on folio $1^{\mathrm{r}}{ }^{33}$ Richard Thomas is notorious for removing important medieval manuscripts from major libraries and never returning them. ${ }^{34}$ Most notably, he was responsible for the removal of the Hendregadredd manuscript, NLW 6680B, from the Hengwrt library, during his visit in

\footnotetext{
32 Bartrum, 'Further Notes', 102. Lhwyd notes the presence of William Salesbury's manuscript in Bodysgallen in his Parochialia, in which he quotes the version of Englynion y Beddau contained therein: Edward Lhuyd, Parochialia; being a summary of answers to "Parochial Queries in order to a Geographical Dictionary, ETC, of Wales, ed. Rupert H. Morris, Archaeologia Cambrensis, 6th ser., 9-11 (1909-11), i, pp. 154-5. Lhwyd also used Salesbury's manuscript in the compilation of the 'Alphabetical Bonedd y Saint': Bartrum, 'Late Additions', 79 and 81-4; Lhuyd, Parochialia, ii, p. 12, n. 1; Owen Jones, Edward Williams and William Owen Pughe, The Myvyrian Archaiology of Wales
}

(Denbigh, 1870), p. 417. The Myvyrian Archaiology text was taken from the expanded version of the Alphabetical Bonedd in BL Add. 14928, written by Lewis Morris: Bartrum, 'Late Additions', 83.

33 See William Llewelyn Davies, 'Thomas, Richard (1753-1780)', in The Dictionary of Welsh Biography down to 1940, under the auspices of the Honourable Society of Cymmrodorion, ed. John Edward Lloyd, R. T. Jenkins et al. (London, 1959), pp. 961-2, available online through the Dictionary of Welsh Biography website: < http://yba.llgc.org.uk/en/s-THOM-RIC-1753.html> [accessed 15 March 2016].

34 MWM 298. 


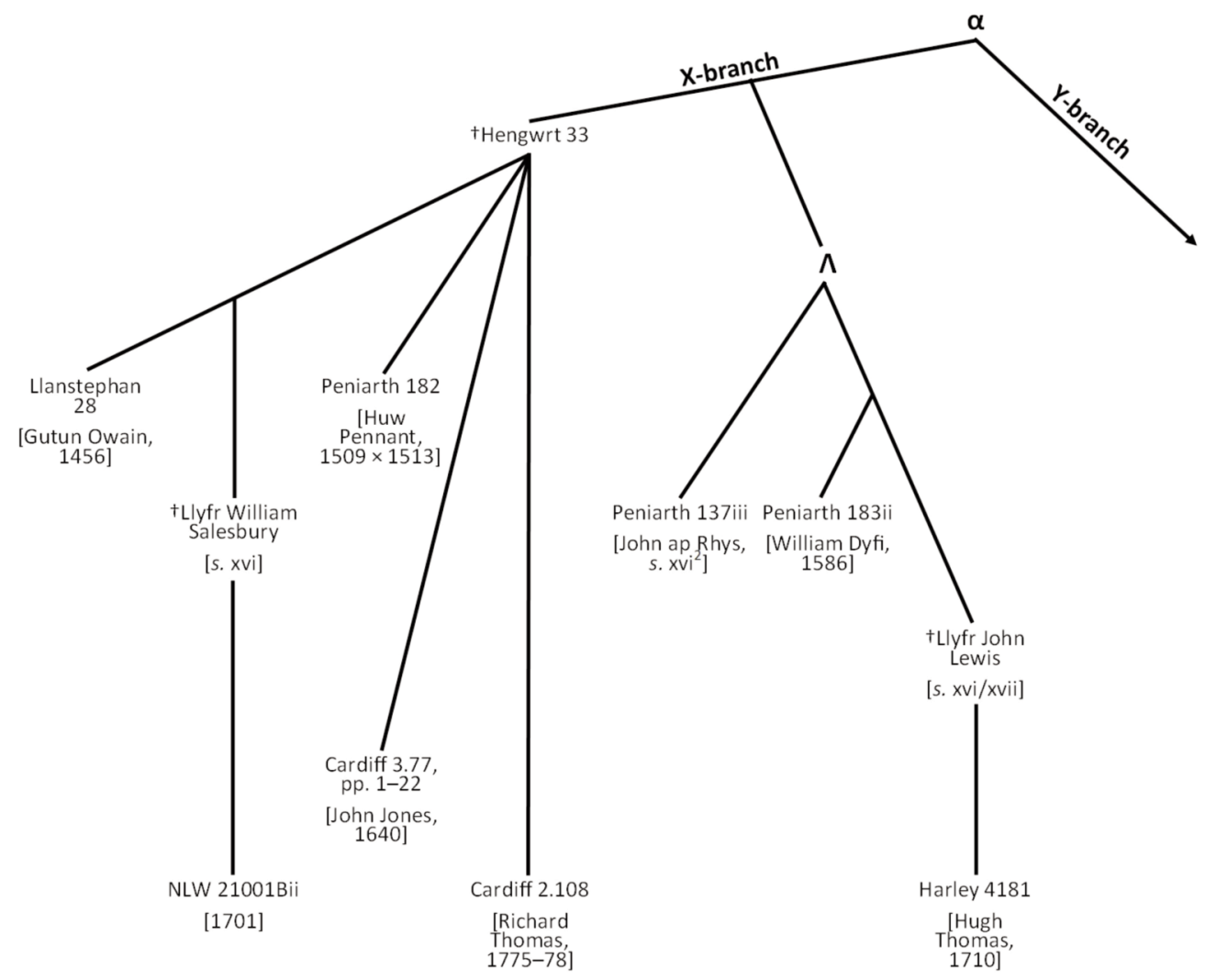

Figure 1. The X-branch of the Llywelyn ab Iorwerth Genealogies

1778. ${ }^{35}$ While at Hengwrt in 1778, he evidently saw Hengwrt 33; although the beginning of Cardiff 2.108 contains the date 1775, it is likely that the transcript of Hengwrt 33 was not made until he obtained permission to use the Hengwrt library three years later. It is reasonably probable that he was responsible for the removal of that manuscript from the collection. It was certainly missing by 1806, as the Hengwrt cataloguer Richard Llwyd reported in a letter written to William Owen Pughe in that year. ${ }^{36}$ The date 1775 probably refers to the time at which Thomas saw the first manuscript that he copied into Cardiff 2.108, now Rylands Welsh 1. ${ }^{37}$ This was also the year in which Thomas graduated from Oxford with a BA. Rylands Welsh 1 seems to have remained in Oxford after Thomas's death, because there appears on folio $66^{\mathrm{r}}$ a note that reads 'J. Price Trin. Coll. Oxon'; this is John Price, the Welshman who was the Bodley librarian from 1768 until his death in

35 See BL Add. 15031, f. 128; Huws, Repertory, $s$. 'NLW 6680B' and 'Thomas, Richard (1753-80)'. Richard Thomas describes his experience in the Hengwrt library in a letter to Owen Jones (Owain Myfyr), written in Peniarth on 17th May 1778 and printed in Handlist, i, p. ix.
36 Handlist, i, p. xxi; Jarman, Ymddiddan, p. 20. The letter is preserved in NLW 13224B, p. 385.

37 For an excellent description of Rylands Welsh 1 by Neil Ker, assisted by Daniel Huws, see N. R. Ker, Medieval Manuscripts in British Libraries, 5 vols (19692002), iii, pp. 468-70. 
$1813 .{ }^{38}$ John Price only moved to Trinity College in June 1789 , so it is likely that he annotated the manuscript on or after that date.

A reasonable picture of the genealogical contents of Hengwrt 33 can be built upon the evidence of the derivative copies, particularly those of John Jones and Huw Pennant in Cardiff 3.77 and Peniarth 182, which were probably direct copies. It is clear that the genealogical sections of Hengwrt 33 all stem from the same corpus of early thirteenthcentury material that is found so frequently in Welsh genealogical manuscripts of the fifteenth to eighteenth centuries. Since this corpus of material is associated particularly with the reign of Llywelyn ab Iorwerth, prince of Gwynedd (d. 1240), I refer to it as the 'Llywelyn ab Iorwerth genealogies'. This genealogical collection encompasses the texts edited separately by Bartrum under his titles 'Plant Brychan', 'Bonedd yr Arwyr', 'Achau Brenhinoedd a Thywysogion Cymru', and 'Hen Lwythau Gwynedd a'r Mars' . ${ }^{39}$ I treat the textual tradition of the Llywelyn ab Iorwerth genealogies at length elsewhere, but a short summary of the conclusions from this study is pertinent for the current examination of Hengwrt 33. ${ }^{40}$ The textual tradition of the Llywelyn ab Iorwerth genealogies divides into two main branches, which I call the 'X-branch' and the 'Y-branch'. The X-branch features Hengwrt 33, initially called ' $\mathrm{X}$ ' by Bartrum, while the Y-branch features Bartrum's lost ' $\mathrm{Y}$ ' manuscript, copied by John Jones into Cardiff 3.77, pp. 32-100. ${ }^{41}$

So far we have discussed five manuscripts that descend, directly or indirectly, from Hengwrt 33, and a further three that stem from a sister copy $(\Lambda)$. The suggested relationships between these manuscripts are shown in figure 1. It is instructive to consider all of the contents of these manuscripts that might be related to the contents of Hengwrt 33. In the following two tables I list all of the related contents, firstly of the five manuscripts that derive from Hengwrt 33, and secondly of the three manuscripts descended from $\Lambda$. For ease of comparison, the terms used to describe the texts do not stray far from the terms used by William Maurice to describe the contents of Hengwrt 33 in 1658.

It should be clear that, in most of the copies and relatives of Hengwrt 33, the order of the texts has been somewhat altered. Considering the contents lists printed in table 1 , Llanstephan 28 would appear to be the only copy preserving the correct order. ${ }^{42}$ The order of texts in Llanstephan 28 agrees with Edward Lhwyd's 1696 catalogue against William Maurice in placing O Oes Gwrtheyn and the king-list either side of the Cronicl byr, and since this ordering is found too in Cwrtmawr 453, another copy of Hengwrt 33 discussed below, it would appear that the 1696 catalogue preserves the original order of the manuscript more faithfully than the Wynnstay 10 copy of the 1658 catalogue. The misplacement of $O$ Oes Gwrtheyrn in Wynnstay 10 also had the effect of separating the two items labelled 'Plant Brychann, a llawer o bethau Achawl (neu Geneologiol)' and 'Llyfr Bonedd'. If these two 'items' followed on immediately from each other in Hengwrt 33, however, there is no need to decide which sections of the genealogical material should be assigned to each heading. ${ }^{43}$ The two titles probably reflect William Maurice's own perceived division of the material edited as $\S \S 1-10$ of the Llywelyn ab Iorwerth genealogies in the appendix to this article.

38 David Vaisey, 'Price, John (1735-1813)', Oxford Dictionary of National Biography (Oxford, 2004) $<$ http://www.oxforddnb.com/view/article/22757> [accessed 15 March 2016].

39 EWGT 75-120.

40 The textual tradition is fully explored in my PhD thesis, entitled 'Medieval Welsh Genealogy: Texts, Contexts and Transmission'.

41 Cf. Bartrum, 'Achau', 201-4.

42 Bartrum came to the same conclusion: 'Achau', 204.

43 EWGT 75 
Table 2. The contents of Hengwrt 33's descendants that also appeared in Hengwrt 33

\begin{tabular}{lll}
\hline Derived from Hengwrt 33 & Pages/fols & Related Contents \\
\hline Llanstephan 28 & $69-75$ & Bonedd y Saint \\
(Gutun Owain, 1456[?]) & $75-80$ & Plant Brychan etc. \\
& $80-86$ & Ach Llywelyn ab Iorwerth etc. \\
& $86-92$ & O Oes Gwrtheyrn \\
& $92-94$ & Cronicl byr yn dechrau yn oes Arthur \\
Peniarth 182 & $94-96$ & Enwau Brenhinedd y Brytaniaid \\
(Huw Pennant, $1509 \times 1513)$ & $13-21$ & Ach Llywelyn ab Iorwerth etc. \\
& $22-24$ & Plant Brychan etc. (part 1) \\
& $24-34$ & O Oes Gwrtheyrn \\
& $34-37$ & Cronicl byr yn dechrau yn oes Arthur \\
& 39 & Bonedd y Saint (frag.) \\
& $39-41$ & Plant Brychan etc. (part 2) \\
& $42-44$ & Enwau Brenhinedd y Brytaniaid \\
Cardiff 3.77 & $63-74$ & Bonedd y Saint \\
(John Jones, 1640) & $155-165$ & Llyfr Theophrastes \\
& $1-10$ & Ach Llywelyn ab Iorwerth etc. \\
NLW 21001Bii & $10-19$ & Plant Brychan etc. \\
(1701) & $20-22$ & Enwau Brenhinedd y Brytaniaid \\
Cardiff 2.108 & $180^{\mathrm{v}}-182^{\mathrm{v}}$ & Englynion Duad \\
(Richard Thomas, 1775) & $190^{\mathrm{v}}-193^{\mathrm{v}}$ & Plant Brychan etc. \\
\hline
\end{tabular}

Table 3. The contents of $\Lambda$ 's descendants that also appeared in Hengwrt 33

\begin{tabular}{lll}
\hline Related to Hengwrt 33 & Pages/fols & Related Contents \\
\hline Peniarth 183ii & $259-266$ & Bonedd y Saint \\
(William Dyfi, 1586) & $266-268$ & Plant Brychan \\
& $268-272$ & O Oes Gwrtheyrn \\
Harley 4181 & $25^{\mathrm{v}} \& 26^{\mathrm{v}}-27^{\mathrm{r}}$ & Bonedd y Saint \\
(Hugh Thomas, 1710) & $25^{\mathrm{v}}-26^{\mathrm{v}}$ & Plant Brychan \\
Peniarth 137iii & $194-195$ & O Oes Gwrtheyrn \\
$\left(\right.$ s. xvi $\left.{ }^{2}\right)$ & $195-197$ & Cronicl byr yn dechrau yn oes Arthur \\
& $197-198$ & Plant Brychan (sons) \\
& $199-204$ & Bonedd y Saint \\
& 204 & Plant Brychan \\
\hline
\end{tabular}

One interesting feature of tables 2 and 3 above is the appearance of Llyfr Theophrastes in Peniarth 182. ${ }^{44}$ This is a Welsh translation of a tract allegedly composed by the philosopher Theophrastus, a pupil of Aristotle, preserved in Latin translation in Jerome's

44 The text is printed in Th. M. Chotzen, 'La "Querelle des Femmes" au Pays de Galles', Revue Celtique, 48 (1931), 42-93 (46-50). 
Adversus Jovinianum. ${ }^{45}$ The tract argued that a wise man should avoid marriage to a woman. From the twelfth century onwards, thanks to the authority of Jerome, Theophrastus's tract became widely known in the Latin West. ${ }^{46}$ Nevertheless, only two other vernacular translations survive from the period: an Italian translation, which appears in two fifteenth-century Italian manuscripts, and a Czech translation, published in print in $1509 .{ }^{47}$ The Welsh translation is a third, and it clearly existed as early as the time at which Hengwrt 33 was written. ${ }^{48}$

The appearances of Englynion Duad in NLW 21001Bii, of O Oes Gwrtheyrn in Llanstephan 28, Peniarth 182, Peniarth 183ii and Peniarth 137iii and of Cronicl byr yn dechrau yn oes Arthur in Llanstephan 28, Peniarth 182 and Peniarth 137iii are equally notable, and these are dealt with more fully in the next two sections.

\section{Poetry}

According to Maurice's catalogue, Hengwrt 33 contained several poetic texts. One was the prophetic poem Anrheg Urien, the earliest extant copies of which are found in the White Book of Rhydderch and Red Book of Hergest. ${ }^{49}$ Another was attributed to Taliesin and named Marwnad Iago mab Beli, presumably an elegy for the early seventh-century king of Gwynedd of that name. ${ }^{50}$ Marged Haycock has suggested that this may have been a version of the prophetic poem Dygogan Awen, found in the Book of Taliesin, which refers to the death of a Iago ap Beli. ${ }^{51}$ A third poem, referred to in Wynnstay 10 as Gwaith Merddyn yw Barchell, may have been a version of the Oianau, one of the Myrddin poems found in the Black Book of Carmarthen. ${ }^{52} \mathrm{~A}$ fourth, absent from the list in Wynnstay 10 but present in Lhwyd's 1696 catalogue, was an awdl by the bard Adda Fras. Later poetic references to Adda Fras portray him as a master poet and composer of prophecies. ${ }^{53}$ The

45 For critical editions of the Theophrastus tract preserved by Jerome, see F. Bock, Aristotles, Seneca, Theophrastus, de matrimonio, Leipziger Studien, 19.1 (Leipzig, 1899), pp. 60-4, and E. Bickel, Diatribe in Senecae philosophi fragmenta. Vol. 1: Fragmenta de matrimonio (Leipzig, 1915), 388-90. For manuscripts containing the tract as an individual item, see Charles B. Schmitt, 'Theophrastus', Catalogus translationum et commentariorum: Medieval and Renaissance Latin translations and commentaries: annotated lists and guides, 2 (1971), 239-322 (313-14).

46 See Charles B. Schmitt, 'Theophrastus in the Middle Ages', Viator, 2 (1971), 251-70; idem, 'Theophrastus', 245-6.

47 Schmitt, 'Theophrastus in the Middle Ages', 267-8; idem, 'Theophrastus', 245.

48 Chotzen claimed that Huw Pennant had translated the work ('La "Querelle des Femmes", 46), but this is based solely on the presence of Pennant's signature at the bottom of the final page of the text. Pennant signed his name in a number of other places in the manuscript, regardless of which texts were present at those points (e.g. pp. 38, 41 and 45), and so no inference should be drawn from the presence of his signature in association with Llyfr Theophrastes.
49 For the White Book and Red Book texts of Anrheg Urien, which are closely related, see respectively Phillimore, 'Fragment', 100-3 and 125-6 and J. Gwenogvryn Evans, The Poetry in the Red Book of Hergest (Llanbedrog, 1911), pp. 17-18 (cols. 1049-50). For a full study of the poem, including an edition and translation with textual notes, see Manon Bonner Jenkins, 'Aspects of the Welsh Prophetic Verse Tradition in the Middle Ages: Incorporating Textual Studies of the Poetry from "Llyfr Coch Hergest" (Oxford, Jesus College, MS cxi) and "Y Cwta Cyfarwydd" (Aberystwyth, National Library of Wales, MS Peniarth 50)', (unpublished PhD thesis, University of Cambridge, 1990), pp. 120-40.

50 According to the Harleian chronicle (the 'A-text' of Annales Cambriae), Iago ap Beli died about 613: Egerton Phillimore, 'The Annales Cambrice and the Old-Welsh Genealogies from Harleian MS. 3859', Cy 9 (1888), 141-83 (156).

51 Marged Haycock, Prophecies from the Book of Taliesin (Aberystwyth, 2013), pp. 92-3.

52 Llyfr Du Caerfurddin, ed. A. O. H. Jarman (Cardiff, 1982), pp. 29-35 (poem 17).

53 Gwaith Tudur Aled, ed. T. Gwynn Jones (Cardiff, 1926), i, p. 283 and ii, p. 743. 
evidence for his floruit is unclear, but he seems to have lived at some point between the mid-thirteenth and mid-fourteenth centuries. ${ }^{54}$

The reference in Lhwyd's catalogue to an awdl of Adda Fras having been present in Hengwrt 33 can help to certify the claim that a fifth poetic text in the manuscript, Englynion Duad, has survived in extant copies. Englynion Duad refers to a series of five gnomic and religious poems, of which the first was edited by Jackson (as 'Bidiau II'), the remaining four by Jenny Rowland, and the fourth on two further occasions by Nicolas Jacobs. ${ }^{55}$ Jackson was aware of three copies of this material, in NLW Peniarth 102, part i (John Davies, s. xvii ${ }^{1}$ ), NLW 1983B (c.1758; 'Panton 14'), and BL Add. 14873 (William Morris, 1739-60), each of which derived, he suggested, from a lost manuscript written by Dr John Davies of Mallwyd. ${ }^{56}$ The situation was clarified a little by Rowland, who has been followed in this respect by Jacobs. Rowland identified another independent copy of the text, found in BL Add. 31055 (Thomas Wiliems, 1591-96), and also deduced that the copies in NLW 1983B and BL Add. 14873 actually derive from a second extant copy made by John Davies, interleaved into NLW 4973B, his Liber B (c.1620-34) (see figure 2) ${ }^{57}$ Further related material is found in three other manuscripts, namely the Red Book of Hergest (Oxford, Jesus College 111), Oxford, Jesus College 20 and Peniarth 27, part ii, but since this material lacks the exactness in textual correspondence that is displayed by the copies previously mentioned, they do not enter the discussion here. ${ }^{58}$

Rowland asserted that 'the source of Davies' copy can be identified with a great deal of certainty as the lost Hengwrt 33'. ${ }^{59}$ The statement is not accompanied by any particular argument beyond the observation that two of the items attributed to Hengwrt 33 in the Wynnstay 10 catalogue are Englynion Duad and Duad. It is, nonetheless, supported by a few additional factors. In Peniarth 102i, John Davies claims that all of the poetry in his part of the manuscript (pages 1-16), including Englynion Duad, had been copied allan $o$ hen lyfr ar $f e[\mathrm{mrwn}]$, 'out of an old book of vellum'. ${ }^{60}$ Since Davies was a frequent user of Robert Vaughan's library at Hengwrt, it is reasonable to suggest that the old book of vellum in question was Hengwrt 33. ${ }^{61}$ Davies' statement would seem not only to encompass the various poems comprising Englynion Duad, but also another poetic text which follows them: a stray awdl by Adda Fras, concerning the events of Judgement Day. It is known from Lhwyd's 1696 catalogue entry that just such a stray awdl appeared in Hengwrt 33. This strengthens the argument that the hen lyfr ar fe[mrwn] should be equated with Hengwrt 33.

54 Barry J. Lewis and Eurig Salisbury, Gwaith Gruffudd Gryg (Aberystwyth, 2010), p. 144; cf. Raymond Wallis Evans, 'Adda Fras (1240?-1320?)', in The Dictionary of Welsh Biography, p. 4 <http://yba.llgc.org.uk/en/s-ADDA-FRA-1240.html> [accessed 15 March 2016].

55 Kenneth Jackson, Early Welsh Gnomic Poetry (Cardiff, 1935), pp. 9-12 and 35-7; Jenny Rowland, 'Englynion Duad', The Journal of Celtic Studies, 3 (1981), 59-87; Nicolas Jacobs, 'Englynion Calan Gaeaf a'r Misoedd o "Englynion Duad", Studia Celtica, 36 (2002), 73-87; idem, Early Welsh Gnomic and Nature Poetry (London, 2012), pp. 13-16.

56 Jackson, Poetry, pp. 9-12. For Peniarth 102i, see Daniel Huws, 'John Davies and his Manuscripts', in Dr John Davies of Mallwyd: Welsh Renaissace Scholar, ed. Ceri Davies (Cardiff, 2004), pp. 88-120 (p. 113).
57 Rowland, 'Englynion Duad', 59-60. Since Jackson did not use Thomas Wiliems' copy, variants from BL Add. 31055 for Bidiau II are printed in ibid., 70 .

58 For recent consideration of the variation between all these copies, see Jacobs, 'Englynion', 73-5.

59 Rowland, 'Englynion Duad', 60. Jacobs agreed with her: 'Englynion', 74. Cf. Huws, 'John Davies', p. 113.

60 The rest of the text is obscured due to damage to the corner of the page, but a similar heading is given in NLW 4973B: allan o hen lyfr arall ar femrwn fel hyn, 'out of another old book, as follows': Rowland, 'Englynion Duad', 60.

61 For Davies's use of Robert Vaughan's library, see Huws, 'John Davies', p. 90. For Robert Vaughan's tribute to John Davies upon the latter's death, see 


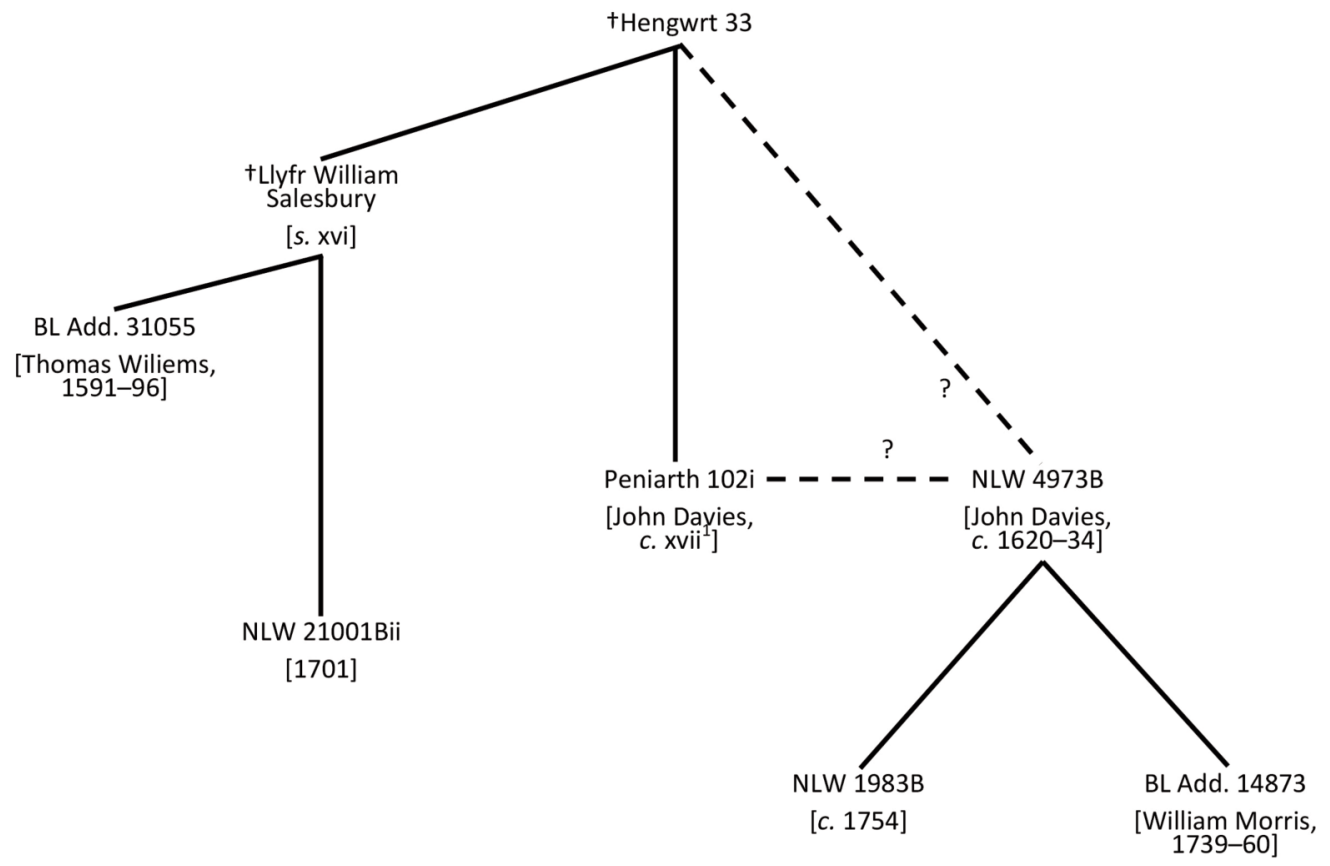

Figure 2. The suggested relationships between the witnesses to Englynion Duad

The additional copy of Englynion Duad found in NLW 21001Bii, the copy of William Salesbury's lost manuscript, as delineated in table 2 above, clarifies the scenario in a number of ways (cf. figure 2). Firstly, since it can be demonstrated that some of the genealogical texts in NLW 21001Bii derive from Hengwrt 33, it is very likely that its text of Englynion Duad does too. Secondly, the version of Englynion Duad in NLW 21001Bii is very closely related to Thomas Wiliems' copy in BL Add. 31055, both of them sharing idiosyncrasies and defects that are absent from John Davies' copies. For example, both texts end prematurely at the same place, half way through a stanza. ${ }^{62}$ This should be considered alongside Rowland's observation that the appearance of the form Deo for Duw in BL Add. 31055 indicates that Wiliems' copy derives from 'an intermediate copy by William Salesbury or his school'. ${ }^{63}$ The use of Latinate Deo for Duw is a peculiar feature of Salesbury's Welsh writing. ${ }^{64}$ The presence in the BL Add. 31055 copy of Camberaec for Gymraeg, another of William Salesbury's forms, argues for the same thing. ${ }^{65}$ Both of these features are, needless to say, present in NLW 21001Bii, leading one to conclude that Thomas Wiliems' copy of Englynion Duad was, like the copy in NLW 21001Bii, taken from the lost book of William Salesbury, which itself contained texts ultimately derived from Hengwrt 33.

Rhiannon Francis Roberts, 'Dr John Davies of Mallwyd: A Biographical Survey', in Dr John Davies, pp. $17-59$ (p. 58).

62 Stanza III.13 in Rowland's edition.

63 Rowland, 'Englynion Duad', 61.
64 Geiriadur Prifysgol Cymru, ed. R. J. Thomas et al. (1950-2002), s.v. Duw.

65 Cf. W. Alun Mathias, 'Gweithiau William Salesbury', Journal of the Welsh Bibliographical Society, 7 (1952), 125-43 (131). 
If the copies of Englynion Duad in Peniarth 102i, BL Add. 31055 and NLW 21001 Bii all derive from Hengwrt 33, the independent status of the partial copy in Liber B is put into question. Liber $B$ contains only the first fourteen stanzas, those labelled 'Bidiau II' by Jackson. The text is virtually identical to that of Peniarth 102i. It is indeed possible that the Liber $B$ text was copied from Peniarth 102i, rather than directly from Hengwrt 33. Only two small details point either way, neither conclusively. At 3c, Liber B has deueiriawg ('deceitful') and Peniarth 102i has daueiriawc, against edeveiriawc in BL Add. 31055 and NLW 21001Bii and deueirya6c in the Red Book. ${ }^{66}$ Liber B preserves an older spelling than Peniarth 102i, although John Davies, if he did take the Liber B copy from Peniarth 102i, might have corrected what he knew to be his own accidental modernisation. At 14c, both of Davies' copies, probably incorrectly, have cost for tost, the latter being the reading of BL Add. 31055, NLW $21001 \mathrm{Bii}$ and Jesus 20. ${ }^{67}$ Either this error was copied from Peniarth 102i, Davies' full copy of Englynion Duad, to his partial copy in Liber B, or else he made the same simple mistake while copying Hengwrt 33 on two separate occasions.

\section{Chronicles}

Hengwrt 33 apparently contained two chronicles. One was the vernacular chronicle known as $O$ Oes Gwrtheyrn. This text is found in Peniarth 182 and Llanstephan 28, two derivatives of Hengwrt 33, as shown in tables 2 and 3 above. It also appears in Peniarth 137iii and Peniarth 187ii, two descendants of $\Lambda$, and so must have been transmitted along the same channels as the Llywelyn ab Iorwerth genealogies. The other chronicle is listed in Wynnstay 10 as Chronicl byrr yn dechreu yn Oes Arthur, Pan las Arthur, 'A short chronicle starting in the age of Arthur, when Arthur was killed'. This is undoubtedly the short chronicle called 'Oed yr Arglwydd' by Owain Wyn Jones, which follows directly on from $O$ Oes Gwrtheyrn in Peniarth 182, Llanstephan 28 and Peniarth 137iii. ${ }^{68}$ The first line of this text, as printed in the appendix to this article, is Oyd ar Arglwyd pan las Arthur yg gad Gamlan: pim cant a deugeint mlined oed y oyd, "The age of the Lord when Arthur was killed in the battle of Camlan: five hundred and forty years was his age'. Maurice seems to have attempted to identify the chronicle by printing a few words ('pan las Arthur') from its first line.

The only serious attempt to study the manuscript tradition of $O$ Oes Gwrtheyrn was made by Owain Wyn Jones in his 2013 doctoral thesis. ${ }^{69}$ Jones identified fifteen copies or partial copies of the text, of which seven derive from other extant copies. The remaining witnesses resolve themselves into two groups, belonging to two separate branches of the textual tradition. ${ }^{70}$ One of these two branches includes Llanstephan 28 and Peniarth 182. It is more than reasonable to assume that the texts of $O$ Oes Gwrtheyrn in both of these manuscripts derive from Hengwrt 33. Jones notes that Peniarth 182, the later

\footnotetext{
66 Cf. Jackson, Poetry, pp. 33 (stanza 7) and 35 (stanza 3); Jacobs, Poetry, p. 9 (stanza 7).

67 Cf. Jackson, Poetry, pp. 34 (stanza 12) and 37 (stanza 14); Jacobs, Poetry, p. 10 (stanza 12).

68 Owain Wyn Jones, 'Historical Writing in Medieval Wales' (unpublished PhD thesis, Bangor University, 2013), p. 291.

69 Ibid., pp. 287-316. Jones included an edition and
}

translation of the text as an appendix. Otherwise the only available text is that of the Red Book of Hergest, published in John Rhŷs and J. Gwenogvryn Evans, The Text of the Bruts from the Red Book of Hergest (Oxford, 1890), pp. 404-6. The Red Book text is incomplete, breaking off half way through the annal for 1210 .

70 See the stemma in Jones, 'Historical Writing', p. 
manuscript, cannot derive from Llanstephan 28. ${ }^{71}$ The latter contains a text that has been subject to numerous shortenings and omissions, of a piece with the treatment of the genealogical texts copied into the same manuscript.

The picture is complicated by two further witnesses that Jones identifies as members of the same branch. These witnesses are NLW Peniarth 135, a composite manuscript written by Gruffudd Hiraethog and other contemporaries between 1556 and 1564 (O Oes Gwrtheyrn on pages 66-71 in the hand of Gruffudd Hiraethog), and NLW Cwrtmawr 453, pages 9-24, written by Robert Vaughan between $c .1615$ and $1630 .{ }^{72}$ Jones argues that Peniarth 135 derives from the same common source as Peniarth 182 and Llanstephan 28. Since we know this source to be Hengwrt 33, it would appear that Gruffudd Hiraethog had access to the latter. Jones positions Peniarth 135 on his stemma slightly closer to Peniarth 182 than to Llanstephan 28, though it would appear that the evidence quoted for this arrangement is indicative of the idiosyncrasy of Llanstephan 28 rather than the shared innovation of Peniarth 135 and Peniarth 182. The text of O Oes Gwrtheyrn in Peniarth 135 would appear then to be an independent copy of the text in Hengwrt 33.

Cwrtmawr 453 exhibits a more complex copy of $O$ Oes Gwrtheyrn, as Jones explains. ${ }^{73}$ Robert Vaughan prefaces his copy with the following statement:

Allan o hen llyvrae memrwm wedi eu scrivennu ers gwell no .300. mlynedh y cawd y cofion hynn.

These records were taken out of old vellum books written more than 300 years ago.

According to Jones, Vaughan has attempted to combine two texts of $O$ Oes Gwrtheyrn, one taken from each branch of the textual tradition. One of these copies was close to the derivatives of Hengwrt 33, but further precision is made impossible by the act of textual conflation. However, Vaughan also copied two other texts into this part of Cwrtmawr 453, which he did not attempt to conflate. The first was the short chronicle Oed yr Arglwydd, prefaced by the statement that: Allan o vn or llyfrae dywededic vchod y cawd hyn sydh yn calyn $[\mathrm{sic}],{ }^{74}$ 'that which follows was taken out of one of the books mentioned above'. The second was a list of Geoffrey of Monmouth's kings of Britain: or vn llyfr y cawd hyn, 'this was taken from the same book'. Each of these texts, like O Oes Gwrtheyrn, was found in Hengwrt 33. What is more, comparison with the copies of these texts in Llanstephan 28, Peniarth 182 and, for the king-list, Cardiff 3.77, shows that the Cwrtmawr 453 texts derive from the common source. Hengwrt 33 was evidently one of Vaughan's llyorae memrwm wedi eu scrivennu ers gwell no.300. mlynedh, showing that Vaughan had probably acquired the manuscript for his library by 1630. Vaughan's copies of these texts are particularly useful because of the care that he took to preserve the form of his exemplar. For this reason, Cwrtmawr 453 is used as the base text for the versions of Oed yr Arglwydd and the kinglist edited in the appendix to this article.

71 Ibid., p. 296. 109.
73 Jones, 'Historical Writing', p. 297.

74 Cf. Geiriadur Prifysgol Cymru, s.v. calynaf. 


\section{Date and Provenance}

The only previous attempt to estimate the date of Hengwrt 33 was made by Peter Bartrum. ${ }^{75}$ Bartrum based his opinion on John Jones' suggestion that the manuscript dated to 400 years before 1640 , namely to $c .1240$. Bartrum pointed out that Jones placed Peniarth 16vi, a fragment of the late thirteenth-century Dingestow manuscript, about 600 years before his own time, and so went on to suggest that, if Jones had overestimated the date of Hengwrt 33 by the same proportion, the latter manuscript should date to $c .1400$. In my opinion, what this information actually tells us is that John Jones was not a reliable judge of manuscript date. Robert Vaughan, on the other hand, who guessed that the manuscript was written just over 300 years before his own time, may not have been too far wide of the mark.

Valuable testimony to the manuscript's date is provided by the chronicle text Oed yr Arglwydd. The final item in this chronicle is the death of Edward I and accession of Edward II in 1307. This is the only good and reliable evidence for the terminus post quem of Hengwrt 33. Moreover, the fact that the chronicle is not continued further than 1307 might suggest that Hengwrt 33 was not written too much later than that date, though this argument cannot be pushed too far.

An early fourteenth-century date is suggested by another plank of evidence: the orthography of Hengwrt 33's copies. Of these copies, only John Jones's Cardiff 3.77 and Robert Vaughan's Cwrtmawr 453 make any attempt to preserve the medieval orthography of their exemplar. Cardiff 3.77 is particularly useful. John Jones's orthographical habits in this manuscript are readily discernible through a comparison between his copied texts and those of his exemplars that survive. Two such exemplars are Peniarth 16vi, the detached portion of the Dingestow manuscript, and Peniarth 27ii, the texts of Bonedd $y$ Saint in each of which were copied by John Jones into Cardiff $3.77 .{ }^{76}$ A comparison between these two manuscripts and Cardiff 3.77 shows that John Jones might change any aspect of the orthography of his exemplar, but that he does so far more frequently and consistently with consonants than with vowels. For example, he regularly changes initial $c$ for $/ \mathrm{k} /$ to $k$; internal and final $c$ for $/ \mathrm{g} /$ to $g$; and $l l$ for $/ \mathrm{t} /$ to $l$ or $l$. He also invariably changes the fricative spellings $c h$ for $/ \chi /$ and $t h$ for $/ \theta /$ to $c$ and t respectively. ${ }^{77}$ Spellings of vowels, on the other hand, whilst occasionally modernised, are often left as they are in his exemplars. This makes particularly striking the prevalence of spellings in $y$ in Cardiff 3.77's copy of the genealogical sections of Hengwrt 33. For example, of the 116 occurrences of the diphthong /ei/, 28 of them (24\%) use the spelling ey rather than $e i .^{78}$ This is especially notable because Cardiff 3.77's copy of Peniarth 27ii shows that Jones might update spellings in ey to ei, as with ymeysyn, copied as yMeisyn into Cardiff 3.77. It is reasonable to assume that in Hengwrt 33 itself, within the relevant portion of text, the relative proportion of spellings in ey to spellings in $e i$ was actually greater than $24 \%$. Cardiff 3.77's copy of Hengwrt 33 also displays occasional instances of $y$ used for $/ \mathbf{i} /$, /it/ and /i/, as in Vendygeyd, Heylyn and Ledyeyt. Spellings such as these are particularly character-

${ }^{75}$ EWGT 76. Nesta Lloyd expressed scepticism about Bartrum's methodology: 'History of Welsh Scholarship', p. 155.

${ }^{76}$ See above, p. 71, n. 13. For the orthography of Peniarth 16vi, see Russell, 'What did Medieval Welsh Scribes do?', 94-6.
77 See too the introduction to the appendix of this article.

78 The following were excluded from the analysis: Keynweyn (second syllable), Kyndyyrn, mibion, Rydyrn, Endiyrnn, Deyrnllug (twice), Geneilles, gwraig, Kadeyrn, Gwrthyrn, Rydeyrn, Endeyrn, Gorthyyrn. 
istic of the Welsh manuscripts of North Wales written in the second half of the thirteenth century. ${ }^{79}$ The orthographical systems of such manuscripts has been described as ' $i$-shy', because they exhibit a marked preference for spellings in $y$ over spellings in $i$, particularly when compared with the more balanced use of the two letters in the fourteenth century. Perhaps this suggests that the date of Hengwrt 33 cannot be pushed too far beyond the terminus post quem of 1307, and that it might belong to North rather than South Wales. A difficulty is that the only useful example of a contemporary vernacular manuscript from South Wales is the Black Book of Carmarthen, the spelling system of which might not be typical of the south during that period. ${ }^{80}$ For this reason it is not possible to ascertain if the spelling system witnessed in northern manuscripts of the thirteenth century, and perhaps at one time in Hengwrt 33, was used more widely elsewhere in Wales during the thirteenth century.

Other noteworthy features of the orthography of Cardiff 3.77's copy of Hengwrt 33 include the occasional use of $e$ for $/ \partial /$ and $t$ for final /ð/ (e.g. Kenedyr, Lantewyn, e, en; Gweurdyt, Nefyt, Rut). $e$ for /o/ was not unknown in the fourteenth century, when $y$ for /o/ prevailed, though it was far more common in the thirteenth century. ${ }^{81} t$ for final $/ ð /$, on the other hand, was never common, though was used occasionally in both the thirteenth and fourteenth centuries. ${ }^{82}$ Given the 1307 terminus post quem, any fourteenth-century comparisons might prove to be more informative than earlier ones. Of particular significance are the orthographical correspondences with Peniarth 20, a manuscript written in the Cistercian abbey of Valle Crucis in the north-east of Wales in the years around $1330 .{ }^{83}$ Hand B of Peniarth 20 in particular displays many of the same spelling characteristics of Cardiff 3.77's copy of Hengwrt 33: frequent use of $e y$ for /ei/; occasional use of $t$ for final $/ ð /$; and, perhaps most strikingly of all in a fourteenth-century manuscript, relatively frequent use of $e$ alongside $y$ for $/ \partial / .^{84}$ Hengwrt 33 would fit comfortably into the milieu of Peniarth 20; indeed, an association with Valle Crucis itself may not be too far wrong.

Many features of the contents of Hengwrt 33 point towards a Cistercian origin for the manuscript. In particular, a number of the texts seem to have been composed in Aberconwy Abbey. Owain Wyn Jones has argued convincingly that Aberconwy was the centre responsible for the composition of $O$ Oes Gwrtheyrn, a text which was last revised in c.1265. ${ }^{85}$ Likewise, it would appear that the Llywelyn ab Iorwerth genealogies were produced in Aberconwy Abbey between 1216 and 1223, as I argue at length elsewhere. ${ }^{86}$ According to both Tudur Aled and Guto'r Glyn, Adda Fras, the only named poet whose

79 T. M. Charles-Edwards and P. Russell, 'The Hendregadredd Manuscript and the Orthography and Phonology of Welsh in the Early Fourteenth Century', National Library of Wales Journal, 28 (1994), 419-62 (431-2); Paul Russell, 'Scribal (In)competence in Thirteenth-Century North Wales: The Orthography of the Black Book of Chirk (Peniarth MS 29)', National Library of Wales Journal, 29 (1995-96), 129-76 (144); idem, 'What did Medieval Welsh Scribes do?', $88-9$.

${ }^{80}$ For the orthography of the Black Book of Carmarthen, see Paul Russell, 'Scribal (In)consistency in Thirteenth-Century South Wales: The Orthography of the Black Book of Carmarthen', Studia Celtica, 43 (2009), 135-74.
81 Charles-Edwards and Russell, 'Hendregadredd Manuscript', 431.

82 Ibid., 433.

83 J. G. Edwards, review of Brut y Tywysogyon, Peniarth MS. 20, ed. Thomas Jones (Cardiff, 1941), English Historical Review, 57 (1942), 370-5 (373-5); G. and T. M. Charles-Edwards, 'The Continuation of Brut y Tywysogion in Peniarth MS.20', in Essays and Poems presented to Daniel Huws, ed. E. B. Fryde (Aberystwyth, 1994), pp. 293-305 (pp. 296 and 301).

84 G. and T. M. Charles-Edwards, 'Continuation', pp. 298-9; Brut y Tywysogyon, Peniarth MS. 20, ed. Thomas Jones (Cardiff, 1941), p. xvii.

85 Jones, 'Historical Writing', pp. 298-301.

86 Guy, 'Medieval Welsh Genealogy'. 
work was included in the manuscript, was buried at Maenan, the site to which Aberconwy Abbey was moved following Edward's conquest of Gwynedd in 1282. ${ }^{87}$

A significant part of the contents of the manuscript seems to have derived from Aberconwy, but it does not necessarily follow that the manuscript itself was written there. When the whereabouts of the manuscript begin to be discernible, through the copies of the fifteenth and sixteenth centuries, it is located in the north-east of Wales. The earliest derivative is that of Gutun Owain in Llanstephan 28, which, given the evidence of NLW $21001 \mathrm{Bii}$, seems to have been copied at one stage removed from Hengwrt 33. It is wellknown that Gutun Owain maintained strong links with Valle Crucis Abbey, where his uncle Siôn ap Rhisiart was abbot. ${ }^{8}$ He may too have been associated with the Cistercian abbey of Basingwerk, as evidenced by his role as the second scribe of the Black Book of Basingwerk, although, considering the use made of Peniarth 20 in the compilation of the version of Brenhinedd y Saesson in that manuscript, it is possible that the Black Book of Basingwerk was written in Valle Crucis. ${ }^{89}$ Basingwerk may have been where Huw Pennant, the scribe of Peniarth 182, worked, whose brother or uncle Thomas Pennant (d. 1522) became abbot of Basingwerk in 1481. ${ }^{90}$ Thomas Pennant may also have been associated with education at Valle Crucis in the second half of the fifteenth century, perhaps as a student. ${ }^{91}$

Hengwrt 33's association with the Cistercian abbeys of the north east, and particularly with Valle Crucis, may well predate the fifteenth century. Two texts in the manuscript show particular links to Valle Crucis. One is the short chronicle text Oed yr Arglwydd. This text is formed of a series of brief chronological notices extending from the death of Arthur in 540 to the death of Edward I in 1307, but focussing particularly on Welsh political events in the middle decades of the thirteenth century. The first few items are stock events in Welsh chronicles, such as Cadwaladr's journey to Rome and the death of Llywelyn ab Iorwerth, while others are stock events of a broader British significance, such as the arrival of the Normans in Britain in 1066 and the death of Thomas Becket in 1171.

87 Gwaith Tudur Aled, ed. Jones, i, p. 83; Dafydd Johnston, 'Monastic Patronage of Welsh Poetry', in Monastic Wales: New Approaches, ed. Janet Burton and Karen Stöber (Cardiff, 2013), pp. 177-90 (p. 187). The Guto'r Glyn references may be found at <www.gutorglyn.net> [accessed 15 March 2016]: poem 110, lines 59-66, and poem 82, lines 59-62.

88 Gruffydd Aled Williams, 'Owain, Gutun (fl. c.1451-1498)', Oxford Dictionary of National Biography (Oxford, 2004) <http://www.oxforddnb. com/view/article/20982> [accessed 15 March 2016]; Morfydd E. Owen, 'Prolegomena i Astudiaeth Lawn o Lawysgrif NLW 3026c, Mostyn 88 a'i Harwyddocad', in Cyfoeth y Testun: Ysgrifau ar Lenyddiaeth Cymraeg yr Oesoedd Canol, ed. Iestyn Daniel, Marged Haycock, Dafydd Johnston and Jenny Rowland (Cardiff, 2003), pp. 349-84 (p. 351). For Gutun's relationship with Siôn ap Rhisiart, see J. Y. W. Lloyd, The History of the Princes, the Lords Marcher, and the Ancient Nobility of Powys Fadog and the Ancient Lords of Arwystli, Cedewen, and Meirionydd, 6 vols (London, 1881-87), iii, pp. 3856; Ann T. E. Matonis, 'Gutun Owain and his Orbit: The Welsh Bardic Grammar and its Cultural Context in Northeast Wales', Zeitschrift für celtische Philologie, 54 (2004-5), 154-69 (160).
${ }^{89}$ MWM 190, n. 20; Ceridwen Lloyd-Morgan, 'Manuscripts and the Monasteries', in Monastic Wales, pp. 209-27 (p. 218); J. E. Caerwyn Williams, 'Gutun Owain', in A Guide to Welsh literature 1282-c.1550: Volume 2, ed. A. O. H. Jarman and Gwilym Rees Hughes, rev. Dafydd Johnston (rev. edn, Cardiff, 1997), pp. 240-55 (pp. 242-3); Roberts, 'Llawysgrifau Gutun Owain', 99; Brenhinedd y Saesson or The Kings of the Saxons: BM Cotton MS. Cleopatra B $v$ and The Black Book of Basingwerk NLW MS. 7006, ed. Thomas Jones (Cardiff, 1971), pp. xix and xxxii-xl.

90 Matonis, 'Gutun Owain', 164; Lloyd-Morgan, 'Manuscripts', p. 215. For the question of the relationship between Huw Pennant and Thomas Pennant, see Jane Cartwright, 'The Middle Welsh Life of St Ursula and the 11,000 Virgins', in The Cult of St Ursula and the 11,000 Virgins, ed. Jane Cartwright (Cardiff, 2016), pp. 163-85. My thanks to Jane Cartwright for sharing her work with me prior to publication.

91 David Thomson, 'Cistercians and Schools in Late Medieval Wales', Cambridge Medieval Celtic Studies, 3 (1982), 76-80. 
The Cistercians find a place among these miscellaneous records, with their apparent 'foundation' being recorded under 1126.

The majority of the following entries, however, concern Welsh political events in the thirteenth century. The text is particularly interested in castles, notably castles in the north east of Wales. It records the fortification of Diserth castle in Flintshire by Henry III in 1241, and its subsequent destruction by Llywelyn ab Gruffudd in 1263. ${ }^{92}$ Two other records contain features that are unique among Welsh chronicles, including the taking of Carreghofa castle (near Llanymynech in Powys) in $1257^{93}$ and the destruction of Hawarden castle on 26th September 1265; the latter event is only otherwise recorded in the Annals of Waverley and $O$ Oes Gwrtheyrn, without an exact date. ${ }^{94}$ Among obituaries, some are of general significance for North Wales, such as the deaths of Gruffudd ap Llywelyn (1244) and Dafydd ap Llywelyn (1246), whilst some have a greater local significance for the area of Valle Crucis, such as the deaths of Madog ap Gruffudd Maelor, founder of Valle Crucis, in $1236 ;{ }^{95}$ his son Hywel ap Madog in 1268, a unique notice among Welsh records; ${ }^{96}$ and John de Warenne, earl of Surrey and, more importantly in the present connection, lord of Bromfield and Yale, in 1304. ${ }^{97}$ Cumulatively, given the otherwise sparse nature of the chronicle, these notices suggest that Oed yr Arglwydd may have been constructed, using various sources, in Valle Crucis itself, sometime after 1307.

One of Oed yr Arglwydd's sources would appear to have been O Oes Gwrtheyrn. The two chronicles share a number of items in common, particularly for the section of $O$ Oes Gwrtheyrn covering the middle decades of the thirteenth century. ${ }^{98}$ Most striking, however, is the chronology of the first three items in Oed yr Arglwydd: the battle of Camlan in 540, Cadwaladr's journey to Rome in 653, and the rule of Offa in 781. The dates, particularly the latter two, are certainly unorthodox. Nevertheless, they were clearly calculated using the relative chronology provided by $O$ Oes Gwrtheyrn, taking as a starting point the battle of Camlan in 540, a date close to that suggested by various Welsh Latin chronicles. ${ }^{99}$

92 E.g. Peniarth MS. 20, ed. Jones, pp. 199 and 214; Brut y Tywysogyon or the Chronicle of the Princes: Peniarth 20 version, transl. Thomas Jones (Cardiff, 1951), pp. 105 and 113; cf. R. R. Davies, The Age of Conquest: Wales 1063-1415 (Oxford, 2001), pp. 256 and 304; J. Beverley Smith, Llywelyn ap Gruffudd: Prince of Wales (new edn, Cardiff, 2014), p. 154; J. E. Lloyd, A History of Wales from the Earliest Times to the Edwardian Conquest, 2 vols (3rd edn, London, 1939), ii, pp. 699, n. 35, and 732-3.

93 The text reads mccxlvii, or 1247 , but, since the event is associated with the battle of Cymerau, 1257 must have been intended. Presumably an $x$ was omitted at some point while copying the numeral. The most substantial account of the battle of Cymerau is found in the Breviate chronicle (the 'B-text' of the Annales Cambriae): Annales Cambriae, the B Text, from London, National Archives, MS E164/1, pp. 2-26, ed. Henry Gough-Cooper (2015), pp. 82-3 <http:// croniclau.bangor.ac.uk/editions.php $>$ [accessed 15 March 2016]; cf. Smith, Llywelyn, pp. 98-9; Lloyd, History, ii, pp. 720-1.

94 Annales Monastici, volume 2: Annales monasterii de Wintonia (AD 519-1277), Annales monasterii de Waverlei (AD 1-1291), ed. Henry Richards Luard (London, 1865), p. 366; Jones, 'Historical Writing', pp. 414 (line
95), 420 and 429; Smith, Llywelyn, p. 172; Lloyd, History, ii, p. 738. Note that, whereas Cwrtmawr 453 reads vi kl' Obtob', Peniarth 182 reads 6i kl' o Gis tachwedd, dating the event a month later. It is more likely that the Latinate date in Cwrtmawr 453 reflects the reading of Hengwrt 33. This is supported by Peniarth 137iii, which agrees with Cwrtmawr 453.

95 The text has mccxxxy, or 1235; presumably a minim has been lost from the end of the numeral

96 It was known previously that Hywel ap Madog died between September 1267 and December 1269: Lloyd, History, ii, p. 747, n. 162; Huw Pryce, The Acts of Welsh Rulers 1120-1283 (Cardiff, 2005), p. 40.

97 Cf. Peniarth MS. 20, ed. Jones, p. 230; transl. Jones, p. 122. In Peniarth 20, the event is misdated to 1300 .

98 Jones, 'Historical Writing', p. 414, lines 87-95.

99 For the relative chronology of $O$ Oes Gwrtheyrn, see Jones, 'Historical Writing', p. 304. For the battle of Camlan in Welsh Latin chronicles, see Henry GoughCooper, 'Annales Cambriae, from Saint Patrick to AD 682: Texts A, B \& C in Parallel', The Heroic Age: A Journal of Early Medieval Northwestern Europe, 15 (2012), edition $\$ 115<$ http://www.heroicage.org/ issues/15/gough-cooper.php $>$ [accessed 15 March 2016]. 


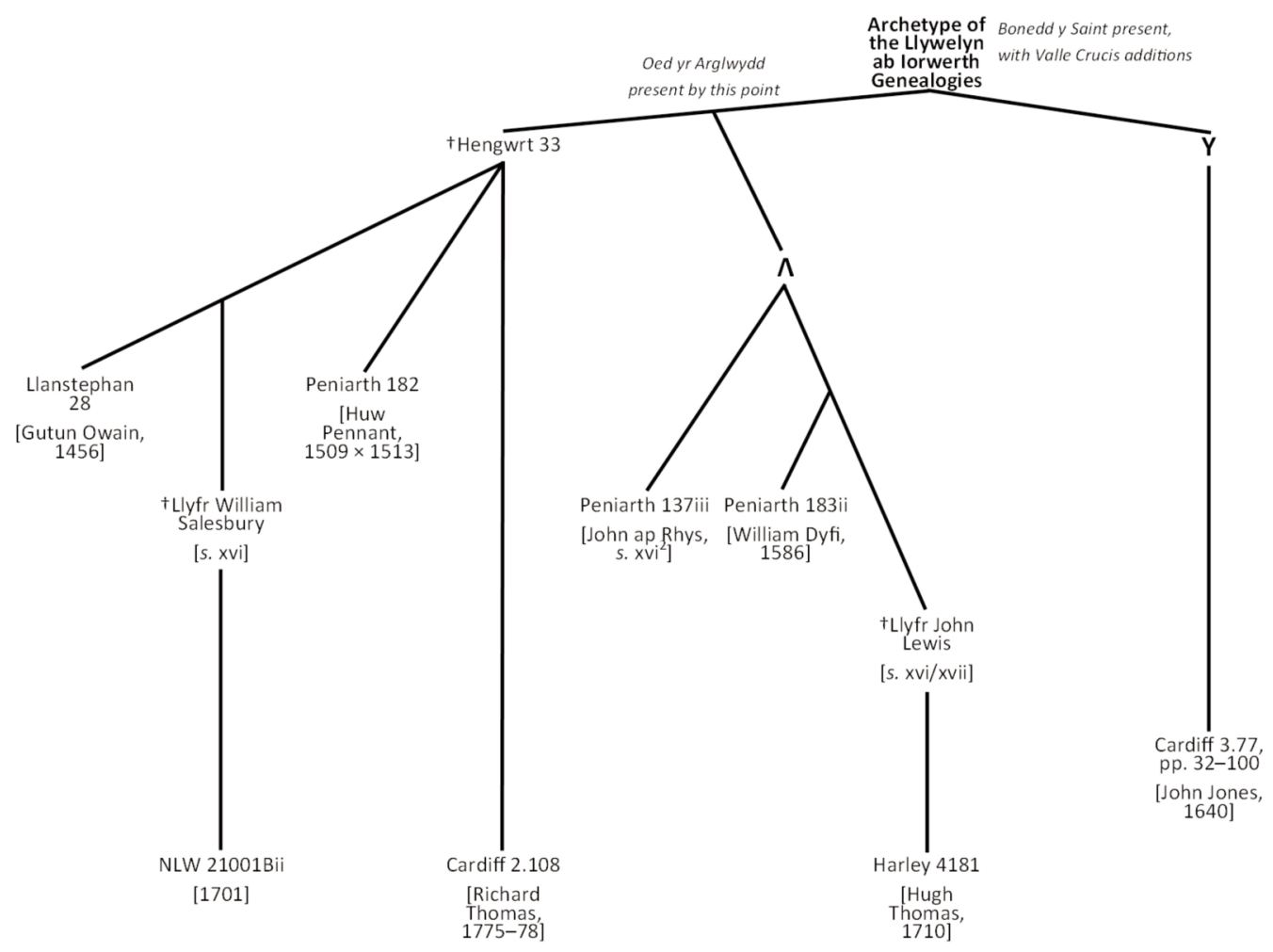

Figure 3. Bonedd y Saint and Oed yr Arglwydd in manuscripts descending from the archetype of the Llywelyn ab Iorwerth genealogies

The second text linked to Valle Crucis is the particular version of Bonedd y Saint that was included in Hengwrt 33. This text is best preserved in Peniarth 182, since the text in Llanstephan 28 has been altered in various ways, whilst the text in NLW 21001Bii has seen a degree of conflation. ${ }^{100}$ Related versions also appear in Peniarth 137iii, Peniarth 183 ii and Harley 4181, the descendants of $\Lambda$. The same version was evidently present in the archetype of the extant manuscripts of the Llywelyn ab Iorwerth genealogies, for it is found in the copy of $\mathrm{Y}$ in Cardiff 3.77, the principal witness to the 'Y-branch' of that textual tradition (see figure 3).

In comparison with earlier copies of Bonedd y Saint, such as that in NLW Peniarth 45 (s. xiv $^{1}$ ), the version in Peniarth 182 and Cardiff 3.77 has received a particular group of additions. ${ }^{101}$ Unfortunately, the version of Bonedd y Saint closest to that of the archetype of the Llywelyn ab Iorwerth genealogies, that in Cardiff Central Library $1.363\left(s\right.$. xiv $\left.^{1}\right)$, is defective at the end, and so one cannot be certain that the additions did not once occur

100 My thanks to Barry Lewis again for his advice on these points. The version in Peniarth 182 is known as ' $\mathrm{H}$ ', and the version in Llanstephan 28 as ' $\mathrm{E}$ ': they are edited respectively in Wade-Evans, 'Bonedd $\mathrm{y}$ Saint, F', 378-84 and idem, 'Bonedd y Saint, E', 16370 .
101 For the Peniarth 45 text, see Baring-Gould and Fisher, Lives, iv, pp. 371-3. Peniarth 45 is useful in this respect because, unlike some of the other early copies, the manuscript remains legible until the end of the text, which reads yma y teruyna bonhed seint kymry, 'here finishes the lineage of the saints of Wales'. 
there too. ${ }^{102}$ Table 4 shows the subjects of these additions, along with their primary cult centres:

Table 4. The additions to the version Bonedd y Saint in manuscripts of the Llywelyn ab Iorwerth genealogies

\begin{tabular}{|c|c|}
\hline Saint (Cardiff 3.77, p. 39) & Cult centre \\
\hline Elfod sant & Abergele $^{103}$ \\
\hline Saeran & Llanynys ${ }^{104}$ \\
\hline Keada o Redynvre & Farndon ${ }^{105}$ \\
\hline Sanffreid & Llansantffraid Glyn Ceiriog, Llansanffraid Glyndyfrdwy etc. \\
\hline Kynhafa! sant ${ }^{106}$ & Llangynhafal \\
\hline Ossụalt ${ }^{107}$ & Croesoswallt (Oswestry) \\
\hline
\end{tabular}

The cult centres are almost all in the north east of Wales (Farndon being just over the border), and lie in a broad ring around Valle Crucis: Abergele, Llanynys and Llangynhafal to the north west, Farndon to the north east, and Llansanffraid Glyndyfrdwy, Llansantffraid Glyn Ceiriog and Oswestry to the south (see figure 4). Valle Crucis had particular connections with some of them: the church of Llansanffraid Glyndyfrdwy had been appropriated to it; at some point between the thirteenth and sixteenth centuries it had acquired fairly extensive lands in the parish of Llansantffraid Glyn Ceiriog; Farndon was some six miles north-east of its extensive manor of Wrexham Abbot; Oswestry was some six miles south of its appropriated church at Chirk and seven miles south of its manor at Halton; and it may have had a grange at Llanynys. ${ }^{108}$ All this implies that the lost manuscript of the archetype of the Llywelyn ab Iorwerth genealogies contained, in addition to a major genealogical text originally composed in Aberconwy, a copy of Bonedd y Saint that had received additions focussed on the area of Valle Crucis's interests. This might suggest that the archetypal manuscript itself was, at some point, associated with that abbey. ${ }^{109}$ Taken together with the evidence for the composition of Oed

102 Cf. A. W. Wade-Evans, Vitae sanctorum Britanniae et genealogiae: The Lives and Genealogies of the Welsh Saints (Cardiff, 1944; new ed. Cardiff, 2013, with introduction and updated bibliography by Scott Lloyd), p. 323, n. 3.

103 Ben Guy, 'The Origins of the Compilation of Welsh Historical Texts in Harley 3859', Studia Celtica, 49 (2015), 21-56 (28); Wade-Evans, 'Bonedd y Saint, E', 170-2.

104 Wade-Evans, 'Bonedd y Saint, E', 172, n. 2; idem, 'Bonedd y Saint, F', 383, n. 5.

105 EWGT 144, n. 66; Wade-Evans, 'Bonedd y Saint, E', 172, n. 3. The localisation of St Chad in Redynvre confirms Melville Richards' speculation that Rhedynfre was the Welsh name for Farndon during the medieval period: 'Arthurian Onomastics', THSC (1969), 250-64 (256, n. 21). Chad was also venerated in Hanmer, near Wrexham, and, more significantly, in Lichfield, making him the patron saint of the entire diocese to the east of Valle Crucis.

106 Following Kynhafal, Cardiff 3.77 lists Kadfarc as the beginning of a new item, but, as Bartrum shows,
Kadfarc should be a continuation of the item about Kynhafal: EWGT 144, n. '68 and 69'. The error probably appeared in the archetype of the Llywelyn ab Iorwerth genealogies, since Cynhafal and Cynfarch are also listed as separate items in Peniarth 182, where their order has been reversed: Wade-Evans, 'Bonedd y Saint, F', 384.

107 Following Oswallt, Cardiff 3.77 begins a new item with Eda Glinfaur, but that name should really continue the genealogy of Oswallt, as in Peniarth 182; cf. EWGT 144, n. '70 and 71'; Wade-Evans, 'Bonedd y Saint, E', 173, n. 8.

108 David H. Williams, Atlas of Cistercian Lands in Wales (Cardiff, 1990), pp. 65-6; Derrick Pratt, 'Valle Crucis Abbey: Lands and Charters', Denbighshire Historical Society Transactions, 59 (2011), 9-55 (19, 267, 33-4 and 40-2).

109 Wade-Evans suggested that the additions were the work of Gutun Owain, on account of their geographical orientation, but he was not aware of the implication of the presence of the same additions in Peniarth 182 and Cardiff 3.77 as well as in 


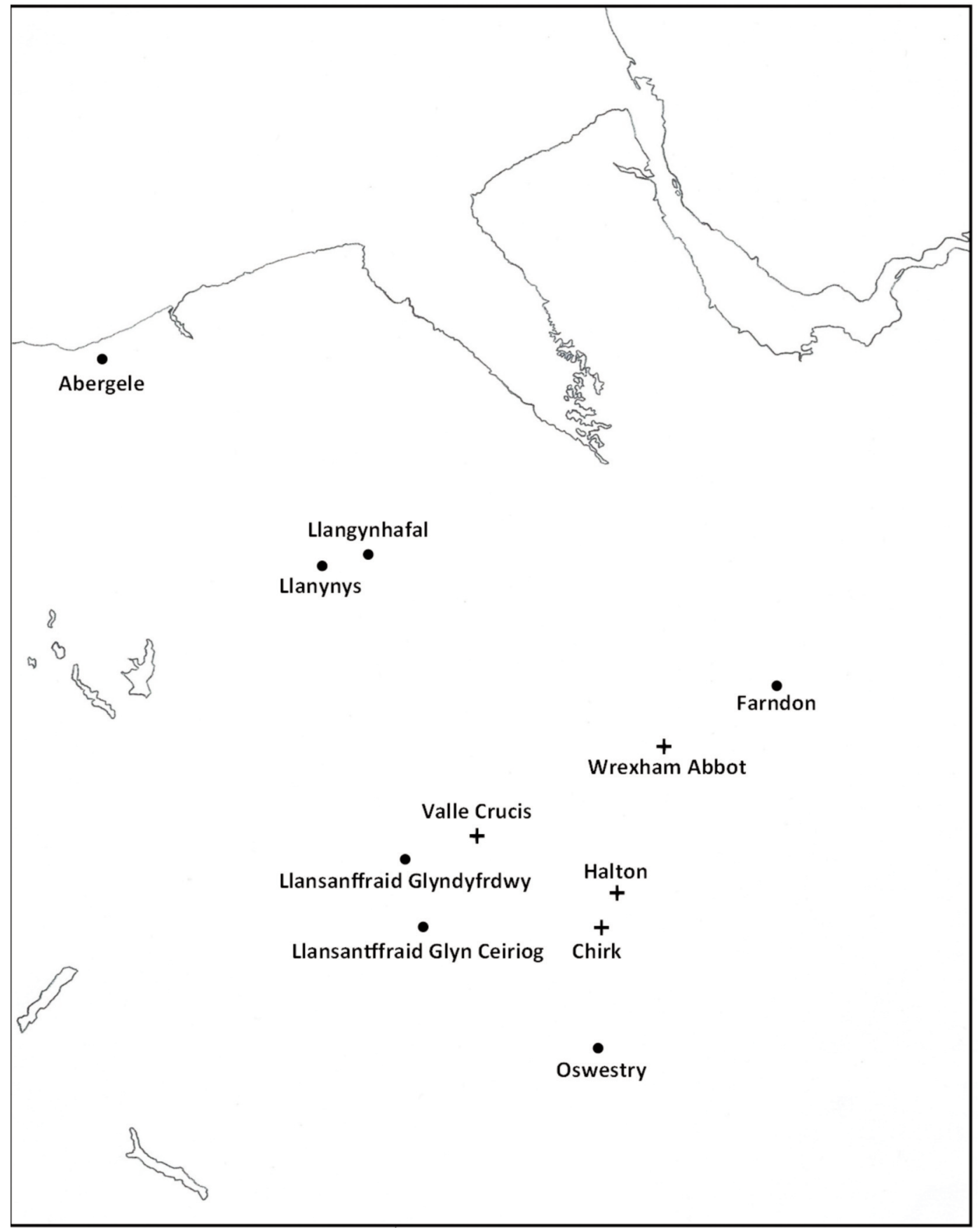

Figure 4. A map of the cult centres of the additional saints (circles) in the version of Bonedd y Saint that accompanies the Llywelyn ab Iorwerth genealogies, in relation to Valle Crucis and some of its properties (crosses) 
yr Arglwydd in Valle Crucis, the close correspondence between the orthography of scribe B of Peniarth 20 and the Cardiff 3.77 copy of Hengwrt 33, and the early association of Gutun Owain and Huw Pennant with Hengwrt 33, I would suggest that Hengwrt 33 was written in Valle Crucis, sometime in the first half of the fourteenth century.

It should be emphasised that this tentative conclusion is only made possible by an analysis that takes into account the textual histories of all the various contents of the manuscript: genealogy, poetry and chronicle. Hengwrt 33 has previously only received attention from scholars focussed on a single genre of text, who therefore did not have to hand as many of the pieces of the now fragmentary puzzle as can be discovered. Holistic approaches to manuscript studies and especially textual history may indeed continue to prove to be a useful tool for advancing our understanding of the past. In the case of Hengwrt 33, it may have provided a new terminus ante quem for almost every text once found in the manuscript (with the exceptions of Bonedd y Saint and the Oianau, both occurring in thirteenth-century manuscripts), and it certainly helps to add nuance and complexity to our understanding of the literary world of the Welsh Cistercians during the high and later Middle Ages. ${ }^{110}$

Llanstephan 28: 'Bonedd y Saint, E', 161; cf. EWGT 78.

${ }^{110}$ I would like to thank Paul Russell and Barry Lewis for suggesting improvements to various drafts of this work. My thanks to Ben Allport for his help creating the map. I would also like to thank the Arts and Humanities Research Council for generously supporting me during the period of research for this article. 


\section{Appendix: Texts from Hengwrt 33}

Below is an attempt to edit a series of texts deriving from Hengwrt 33. These include various sections of the Llywelyn ab Iorwerth genealogies, an awdl by Adda Fras, a short chronicle called Oed yr Arglwydd, and a list of kings taken from Brut y Brenhinedd. Neither the Adda Fras awdl nor Oed yr Arglwydd have appeared in print before, whilst Hengwrt 33's genealogies and king-list have only appeared as part of Bartrum's conflated editions of the relevant texts. ${ }^{1}$ The titles of the texts are taken from the item entries of either the 1658 catalogue or the 1696 catalogue, as listed at the beginning of the article. Following the titles in the headings are the manuscripts used for the base texts. The awdl by Adda Fras, taken from Peniarth 102, is a relatively straightforward transcription, requiring little additional editorial comment. The editing method for the genealogies, chronicle and king-list is more complex, due both to the peculiarities of John Jones' orthographic system and to the necessity to include more extensive variants from other manuscripts.

As is well known, John Jones used a peculiar system of dotting to write Welsh. ${ }^{2}$ The dots would be cumbersome in a modern edition, not least because they can be so easily forgotten or ignored. Since the purpose of the present edition it to reconstruct texts in Hengwrt 33, it has been thought best to interpret Jones' orthography in light of what we know about the norms of medieval Welsh orthography, compared with Jones' treatment of those norms in his other transcriptions. Some of his dots signify that he has changed the medieval orthography of his exemplar in a predictable way, and these dotted letters have been transcribed as follows: $c=c h, \dot{p}=p h, t=t h, u=w$. Other dots were usually added by Jones to clarify the phoneme indicated by particular letters, without any basis in the medieval orthography, and these dots have been ignored: $d \dot{e} \dot{g} k \dot{o} r \dot{y}$. Most confusing of all is his system of using $l=/ 1 /$ and $l=/ 1 /$, since he frequently neglected to add the dot where the $l$ should stand for $/ 1 /$, spelt $l$ in modern Welsh. In the edition below, $l$ is usually transcribed as $l$ and $l$ as $l l$, but instances in which undotted $l$ clearly stands for $/ 1 /$ have been transcribed with an italicised $l$. This has been done so as to avoid an overabundance of $l$ for $/ 1 /$, which would look absurd in the Welsh of any period. Overall, this approach to John Jones' orthography should hopefully result in a text which is both more accessible to readers and a closer approximation to Hengwrt 33's orthography than a literal transcription of Cardiff 3.77 would have been, but one which does not impose upon the text any orthographical feature that is not somehow indicated by John Jones.

The following sigla are used for the variants in the footnotes: ${ }^{3}$

A: NLW Peniarth 182, pp. 13-24 and 39-45 (Huw Pennant, $1509 \times 1513$ ).

B: Cardiff Central Library 3.77, pp. 1-22 (John Jones, 1640).

D: NLW Llanstephan 28, pp. 75-86 and 94-6 (Gutun Owain, 1456[?]).

S: NLW 21001B, ff. 190v-193 (1701).

V: NLW Cwrtmawr 453, pp. 27-38 (Robert Vaughan, c. $1615 \times 1630$ ).

B has been used as the base text for the genealogical sections, with variants provided by ADS, generally quoted in that order. V has been used as the base text for Oed yr Arglwydd,

1 EWGT 75-120.

2 For an analysis of John Jones' orthography, see

Lloyd, 'History of Welsh Scholarship', i, pp. 324-36.
3 The sigla ABD follow Bartrum's usage in EWGT 78-9. 
with variants from $\mathrm{AD}$, and for the king-list, with variants from $\mathrm{BAD}$. If a reading in any of the supporting witnesses has been judged more likely to represent the reading of Hengwrt 33 than the corresponding reading in the base text, then that reading appears in the main text in italics and the reading of the base text is given in the footnotes. The variants are designed to provide a comprehensive indication of the contents of the supporting witnesses. Common variations of orthography have been ignored, as have common variations of popular names, such as Caradog/Cradog or Llywarch/Llowarch. In any footnote a particular variant may be listed as present in multiple witnesses; in these cases, the variant quoted has been taken from the first witness listed, and it can be assumed that the other listed witnesses have an approximate, though not necessarily identical, version of the same reading. In all footnotes the readings of every witness available at that point are indicated. Omission of readings by particular witnesses is indicated by an en-dash (-), while readings that are probably additional to Hengwrt 33's original text are indicated by the function $a d d(s)$.

Punctuation has been added and the initial letters of all proper nouns, including epithets, have been capitalised. Contractions have been expanded in italics; contractions are therefore distinguishable from the readings of other manuscripts incorporated into the main text (also italicised) by the fact that expanded words begin in normal type and are not followed by a footnote. Contractions among the readings of other witnesses included in the main text, which are already italicised, are expanded in normal type. The readings of all witnesses have been taken as they were left by their original scribes, including scribal corrections/additions but ignoring later marginalia. Any gaps that appear to have been left deliberately by the scribes are indicated by [GAP]. Any lacunae or portions of illegible text are indicated by an ellipsis enclosed in square brackets [...]. The page numbers of the base texts appear in square brackets in normal type. The extracts from the Llywelyn ab Iorwerth genealogies have been organised into sections and numbered according to the scheme used in my forthcoming edition of the full archetypal text. Since Hengwrt 33 only contained selected excerpts from the Llywelyn ab Iorwerth genealogies, the section numbering in the edition below is not entirely continuous (e.g. $\S \S 13-26$ of the Llywelyn ab Iorwerth genealogies were not included in Hengwrt 33). Both the awdl by Adda Fras and Oed yr Arglwydd are followed by translations into English, which have been enclosed in square brackets.

PLANT BRYCHAN A LLAWER O BETHAU ACHAWL AND LLYFR BONEDD (Cardiff Central Library 3.77 , pp. 10-19)

$[\$ \mathbf{1 . 1}]^{4}$ Brychan Brycheiniawg ap Cormoc ${ }^{5}$ brenin Iwerddon ${ }^{6}$, a Marchell verch Teudrig ap Teithffalt ap Teithan ap Tuthal ap Ann6n $n^{7}$ Ddu brenin Groeg $i$ vam. ${ }^{8}$

$[\text { text missing }]^{9}$

\footnotetext{
4 This section is absent from B. The text has been provided by A. See below, n. 9 .

5 D; Tormoc A.

6 A; Ewerddon D.

7 A; mam D.

$8 \mathrm{D}$ adds the first portion of text from $\$ 1.2 .1$ : Kynoc ap Brychan.
}

9 See above, p. 73. B leaves a six-line gap before beginning with the last part of $\S 1.3 .10$. A begins with $\S 1$, then skips down to $\$ 1.5$, omitting the partial text on Brychan's daughters preserved by B. D also begins with $\S 1$, followed by the first words of $\$ 1.2 .1$ (Kynoc ap Brychan), but then skips to $\$ 1.3 .11$, the first full section preserved by B. S similarly begins with $\S 1.3 .11$. 
[\$1.3.10] [10] gwreig Tudaw ${ }^{10}$ Pefyr.

[\$1.3.11] Keyngar ${ }^{11}$ ferch Vrychan, mam Kenedyr sant.

[\$1.3.12] Goleu ferch Vrychan yn Llanhesgyn ${ }^{12}$.

[\$1.3.13] Gweurdyt ${ }^{13}$ ferch Vrychan yn Llantewyn.

[\$1.3.14] Tidyei ${ }^{14}$ ferch Vrychan yManaw.

[\$1.3.15] Elinet ${ }^{15}$ ferch Vrychan yGrug Gorsabawl ${ }^{16}$.

[\$1.3.16] Keyndereg ${ }^{17}$ ferch Vrychan yn Tregabaelogfar ${ }^{18}$.

[\$1.3.17] Gwen ferch Vrychan yn Talgarth.

[\$1.3.18] Kenodlon ${ }^{19}$ ferch Vrychan yMynyd ${ }^{20}$ Kymorth.

[\$1.3.19] Klydyei ${ }^{21}$ ferch Vrychan yn Emlyn.

[\$1.3.20] Keynweyn ${ }^{22}$ ferch Vrychan $\mathrm{a}^{23}[11]$ Dwyn $^{24}$ ferch Vrychan yMon.

[\$1.3.21] Tudwystil ferch Vrychan. ${ }^{25}$

[\$1.4] Teir gwraged $\mathrm{a}^{26}$ vu y Vrychan: Eurbraws $2^{27}$ a Rybrawst a Proestri ${ }^{28}$.

[\$1.5] Teir gwelygord seynt Kymru ${ }^{29}$ : Plant Brychan ${ }^{30} \mathrm{a}^{31}$ Phlant Kyneda Wledig a Phlant Kaw o Brydyn ${ }^{32}$.

[§2] Plant Kyndrwyn: Elfan Powys mab Kyndrwyn, Kynon m. Kyndrwyn, Gwyawn m. Kyndrwyn, Riadaf ${ }^{33} \mathrm{~m}$. Kyndrwyn, Haearnllen ${ }^{34} \mathrm{~m}$. Kyndrwyn, Pasgen mab Kyndrwyn, Gwin $^{35} \mathrm{~m}$. Kyndrwyn, Kynwreith ${ }^{36} \mathrm{~m}$. Kyndrwyn, Ebedyn ${ }^{37} \mathrm{~m}$. Kyndrwyn, Kynan $\mathrm{m}$. Kyndrwyn, [12] Gwenalogyt $a p^{38}$ Kyndrwyn, Moruael $a p^{39}$ Kyndrwyn, Ffefur ${ }^{40}$ ferch Kyndrwyn, Medfyl $l^{41}$ ferch Kyndrwyn, Medlan ferch Kyndrwyn, Gwledyr ferch Kyndrwyn, Meisir verch Kyndrwyn ${ }^{42}$, Keynvrit ${ }^{43}$ ferch Kyndrwyn, Heled ferch Kyndrwyn, Gwladus ferch Kyndrwyn, Gwendwyn ferch Kyndrwyn.

[§3] Plant Yaen ${ }^{44}$ : Dirmig ${ }^{45}$ Corne $^{46} \mathrm{~m}$. Yaen, Gwinn ${ }^{47}$ Goluthon $^{48} \mathrm{~m}$. Yaen ${ }^{49}$, Siaun ${ }^{50} \mathrm{~m}$. Yaen, Karadawc ${ }^{51} \mathrm{~m}$. Yaen, Yeuanwy ${ }^{52} \mathrm{~m}$. Yaen, Llychlyn m. Yaen, Eleirch ${ }^{53}$ ferch Yaen, mam Kyduan ${ }^{54}$ m. Arthur.

10 Recte Tudwal.

11 B; Kyngaer D; Kynger S.

12 BD; Llan Hesbyn S.

13 B; Gwenddydd D; Gwawrddydd S.

14 B; Tydie D; Tydei S.

15 BD; Elinor S.

16 BD; Gorsawl S.

$17 \mathrm{~B}$; Keindrec D; Keidderec S.

18 B; Hir ga6aelogwir D; Trigabac lognay S.

19 B; Kendlon D; Kenedlon S.

20 BS; yn y Mynnydd D.

21 BS; Clydai D.

22 B; Keinwen DS.

3 B; - DS.

4 B; Dwynwen DS.

5 S adds Gwennan Mwynwen Gwenrhîw.

$\mathrm{BD} ;-\mathrm{S}$.

D; Eurbrau B; Eurbraist S.

B; Fferescri D; Horestri S.

BAD; Ynys Brydain S.

A adds Brycheiniawg.

BAD; - S.

2 BA; Brydain DS.

BAD; Biaddaf S.
34 A; Haearn[GAP] B; Haiarnllen D; Haiarllen S.

5 BAS; Kwna D.

6 B; Kynwraidd A; Kynwreich DS.

7 B; Ypedyn A; Ehedyn D; Bleddyn S.

8 ADS; [GAP] B.

ADS; [GAP] B.

BA; Seur D; Febar S.

1 BAD; Meddnyl S.

2 ADS; [GAP] B.

3 B; Kyn6ryd A; Kein6ric D; Kenmrit S.

44 BAS; Ywain D. Yaen subsequently appears as Ywain in all of the epithets in D.

$45 \mathrm{BAD} ;-\mathrm{S}$.

46 DS; Torfen B; Korme6 A.

47 BAS; Gweinin D.

48 BAS; Goluthion D.

$49 \mathrm{~S}$ omits the epithets of all the sons from Gwyn Goluthon to Llychlyn.

50 BAD; Siadwn S.

51 SAD; Karudawg B.

52 BAD; Eimanwy S.

53 BAS; Eberth D.

54 ADS; Kytnan B. 
[\$4] Plant Kaw o Dwrkelyn: [13] Dirmig mab Kaw, Kilid ${ }^{55}$ m. Kaw, Ustig m. Kaw, Echymwc $^{56}$ m. Kaw, Kof mab Kaw, Aneirin m. Kaw ${ }^{57}$, Gwydrein ${ }^{58}$ m. Kaw, Samsson ${ }^{59}$ m. Kaw, Bangar ${ }^{60}$ mab Kaw, Kelyn ${ }^{61}$ m. Kaw, Hueil m. Kaw, Gildas m. Kaw, Aedan m. Kaw, Gallgaw m. Kaw ${ }^{62}$, Eirigrawn ${ }^{63}$ m. Kaw, Dyfnwe ${ }^{64}$ m. Kaw, Kowillawg ferch ${ }^{65} \mathrm{Kaw}$ Peithien $^{66}$ ferch Kaw, Gwenawy ferch Kaw, Gwrdelw m. ${ }^{67} \mathrm{Kaw}$, Aneu ${ }^{68} \mathrm{~m} .{ }^{69} \mathrm{Kaw}^{70}$.

[§5] Plant Egri o Dalebolion ${ }^{71}$ a vuant $^{72}$ yn oes Faelgwn ${ }^{73}$ : [14] Nud $^{74} \mathrm{~m}$. Egri, Ronyn ${ }^{75} \mathrm{~m}^{\text {. }}$ Egri, Aeardur ${ }^{76} \mathrm{~m}$. Egri, Geiriat ${ }^{77} \mathrm{~m}$. Egri ${ }^{78}$, Tryderan ${ }^{79} \mathrm{~m}$. Egri, Meyrchiawn m. Egri, Uchno m. Egri ${ }^{80}$, Hed m. Egri, Eblyt m. Egri, Coll ${ }^{81} \mathrm{~m}$. Egri, Glassan ${ }^{82}$ m. Egri, Alan m. Egri, Kamo m. Egri, Belyn ${ }^{83} \mathrm{~m}$. Egri, Elinwy ${ }^{84} \mathrm{~m}$. Egri, Llurig Ros $^{85} \mathrm{~m}$. Egri, Teyrnawg ${ }^{86}$ m. ${ }^{87}$ Egri, Nwy ${ }^{88}$ m. Egri (y gwr y gelwit o'e enw ${ }^{89}$ Karnwy), Lleuned ${ }^{90}$ ferch Egri ${ }^{91}$.

[\$6] ${ }^{92}$ Plant Llywarch Hen ${ }^{93}$ : [15] Gwen m. Llywarch ${ }^{94},{ }^{95}$ Pill m. Llywarch, ${ }^{96}$ Llawr $^{97}$ m. Llywarch, Mechyd ${ }^{98} \mathrm{~m}$. Llywarch ${ }^{99}$, Maen m. Llywarch, Dwywg ${ }^{100} \mathrm{~m}$. Llywarch, Nefyt ${ }^{101}$ m. Llywarch ${ }^{102}$, Sandef ${ }^{103} \mathrm{~m}$. Llywarch, Selyf m. Llywarch, Dilig m. Llywarch, Lliuer ${ }^{104} \mathrm{~m}$. Llywarch, Deigyr ${ }^{105} \mathrm{~m}$. Llywarch, Rut m. Llywarch, Madawg m. Llywarch, ${ }^{106} \mathrm{Medel}^{107} \mathrm{~m}$. Llywarch, Heylyn m. Llywarch, Gwell ${ }^{108} \mathrm{~m}$. Llywarch, Sawyl ${ }^{109} \mathrm{~m}$. Llywarch, Llorien ${ }^{110} \mathrm{~m}$. Llywarch, Keny m. Llywarch, ${ }^{111}$ Llynghedwy ${ }^{112} \mathrm{~m}$. Llywarch, Kynllug m. Llywarch, Llewenyd m. Llywarch, Gorwynon ${ }^{113} \mathrm{~m}$. Llywarch, [16] Riell ${ }^{114}$ ferch Llywarch.

5 B; Kilidd AS; Kelid D.

6 SA; Echyniwg B; Echymawc D.

7 Aneirin m. Kaw BA; - DS.

8 BDS; Gwydreyin A.

BAD; Sampson S.

BD; Bangor A; Kangar S.

1 BAS; K6helyn D.

2 Aedan... Gallgaw m. Kaw BAD; - S.

BDS; Eirgrawn A.

A; Dyfinfe B; Dyfin6e D; Dyssiûc S.

BA; ap D.

BA; Peithin D; Peithieû S.

$\mathrm{BA}$; verch $\mathrm{S}$.

BA; Anrû S.

$\mathrm{BA}$; verch $\mathrm{S}$.

Gwrdelw... Aneu m. Kaw BAS; - D.

BAD; Dalybolion S.

BDS; wnant A.

BS; 6aelgwyn AD. D adds Gwynedd.

BAS; Rudd D.

ADS; Rouyu B.

BAS; Iardd6r D.

BA; Keiriad D; Giriat S.

BAS; Egsi D.

B; Tryderaw A.

Tryderan... Uchno m. Egri BA; - DS.

ADS; Kol B.

ADS; Giassan B.

BS; Kelyn A; K6helyn D.

ADS; Elinw B.

$\mathrm{BS} ;-\mathrm{AD}$.

6 B; Tyrnawg AS; Tyrynoc D.

$\mathrm{BA} ;-\mathrm{D}$.
88 BA; Rrwy D; Nwr S.

89 y gwr. .. o'e enw BS; ag o'i henw y gelwir A.

90 B; Llen6edd A; Llennedd S. y gwr... Lleuned BAS; - D.

91 ferch Egri BAS; - DS.

92 A omits this section.

93 B adds o Benllyn.

$94 \mathrm{~S}$ omits all epithets in this section except that of Riell.

95 D adds Morudd ap Llowarch.

96 D adds Rrenyd ap Llowarch.

97 BS; Lla6or D.

$98 \mathrm{BS}$; - D.

99 m. Llywarch B; - D.

100 BD; Dwyws S.

101 B; - D; Nenyd S.

102 m. Llywarch B; - D.

103 BD; Sandes S.

104 B; Lliner DS.

105 DS; Beigir B.

$106 \mathrm{~S}$ adds Alarch.

107 BD; Medyl S.

108 BS; Gwel D.

109 BS; Sawl D.

110 D; Lloryeu B; Klorien S.

$111 \mathrm{~S}$ adds Kynddylan, Briw un dr [recte unde] Tref Briw hoc e Trefriw, Brwyn unde Moel Drefvrwyn apud Garth Garmon yn tervyny a Nant Trefguraedd. Hec David Lloid ap Edward.

112 D; Llynghedfy B; Llyngeddwy S.

113 B; Gorwynion D; Gowynion S.

114 BD; Rell S. 
[\$7.2 $]^{115}$ [16] Plant ${ }^{116}$ Kynfarch $^{117}$ mab $^{118}$ Meyrchiawn $^{119}$ : Llew m. Kynfarch, Arawn m. Kynfarch, Urien m. Kynfarch, Anarawn ${ }^{120} \mathrm{~m}$. Kynfarch, archesgob Llydaw.

[\$7.1] Plant Urien mab Kynfarch ${ }^{121}$ : Eweyn ${ }^{122}$ m. Urien, Run ${ }^{123}$ m. Urien, Riwallawn m. Urien, Elffyn m. Urien, Pasken m. Urien, Kateel m. Urien ${ }^{124}$.

[\$7.1.1] Kyndyyrn ${ }^{125}$ Garthwys m. Yweyn m. Urien.

[\$7.3 $]^{126}$ [17] Plant Keneu mab Koel: Padern ${ }^{127}$ m. Keneu, Gorust m. Keneu, Garmoniawn $^{128} \mathrm{~m}$. Keneu, Maesgwig Kloff ${ }^{129} \mathrm{~m}$. Keneu.

[\$7.3.1] Edern $^{130}$ m. Padern ${ }^{131}$ m. Keneu.

[\$7.4] Plant Gorwst mab Keneu: Meyrchiawn m. Gorwst, Elifer ${ }^{132}$ Gosgordfawr ${ }^{133} \mathrm{~m}$. Gorwst m. Keneu m. Koel $l^{134}$.

[\$7.5] Plant Meyrchyiawn m. Gorwst ${ }^{135}$ : Kynfarch m. Meirchiawn, Elidir Lydanwyn ${ }^{136} \mathrm{~m}$. Meirchiawn ${ }^{137}$, Idno m. Meirchiawn.

[\$7.6] Plant Idno m. Meirchiawn ${ }^{138}$ : Meurig ${ }^{139}$ ap Idno $^{140}$, Mabon ${ }^{141} \mathrm{~m}$. Idno m. Meirchiawn $a p^{142}$ Gorrwst $^{143} \mathrm{~m}$. Keneu ${ }^{144} \mathrm{~m}$. Koel.

[\$8] [18] Helygu ${ }^{145}$ ag Eluedan ${ }^{146}$, meibyon Hilon ${ }^{147}$ Hwylfawr o'r Gogled $^{148}$.

[\$9.1] Elidir ${ }^{149}$ Mwynfawr mab Gorwst Priodawr m. Gwydwal ${ }^{150}$ m. Dyfynyewal ${ }^{151}$ Hen . Ednyfet m. Maxen Wledig ${ }^{152} \mathrm{~m}$. Llywelyn ewyther ${ }^{153}$ Elen Luydawg.

[\$9.2] Ryderch Hael Glaer ag ${ }^{154}$ Arderch Drut a ${ }^{155}$ Morgant Mwynfawr, meibion Tudwal Tutklyt.

$[\$ 9.3]^{156}$ Gwydien $^{157}$ Astrus ag Enuael ${ }^{158}$, meibion ${ }^{159}$ Deigir m. Dyfynyeal ${ }^{160}$ Hen $^{161}$.

[\$9.3.1] Yeuaf a Cheneu, meibion ${ }^{162}$ y Vrwyder Dirieit ${ }^{163}$ mab Gwydien ${ }^{164}$ Astrus $\mathrm{m}$. Deigir mab Dyfynewal ${ }^{165}$ Hen $^{166} \mathrm{~m}$. Ednyfet mab Maxen m. ${ }^{167}$ Llywelyn. $^{168}$

115 In $\mathrm{B} \$ 7.1$ and $\$ 7.2$ have been transposed, as they are in witnesses of the later tradition associated with Gutun Owain. ADS follow the original order. In $\S 7, \mathrm{~S}$ omits all epithets except for those in headings and that of Mabon ab Idno.

116 BAD; - S.

117 BAD; Llywarch S.

118 BAD; - S.

119 BAD; Meiriawn S.

120 A; Anarun B; Anaran D; Annawn S.

121 BDS; Kyndrwyn A.

122 B; Owain A; Ywain D; Gwehyn S.

123 BAD; - S.

124 Pasken... Kateel m. Urien BAS; - D.

125 B; Kyndeyrn AD; Kyndern S.

$126 \mathrm{~S}$ omits this section.

127 B; Padarn AD.

128 BA; Garmon D.

129 BA; - D.

130 B; Edyrn AD.

131 B; Padarn AD.

132 BAS; Eliuer D.

133 BA; - D; Gosgordd S.

134 m. Keneu m. Koel BA; - D. A adds Godebawg.

135 BA; - D; Grwst S.

136 Elidir Lydanwyn BA; - DS.

137 m. Meirchiawn BA; - D.

138 m. Meirchiawn BAS; - D.

139 BAS; - D.

140 ap Idno BA; - D.
141 BAD; Mabo S.

142 ADS; - B.

143 A; - B; Grwst DS.

$144 \mathrm{~m}$. Keneu BAD; - S.

145 B; Helygy A; Helyg D; - S.

146 ag Eluedan BAD; - S.

147 S; - B; Bibon A; i Lonn D.

$148 \mathrm{~S}$ adds Belygyn ac Elnedan.

149 BAS; Elididir D.

150 BA; Gwydawl DS.

151 B; Dyfnwal AD; Dynynyenal S.

$152 \mathrm{BAD} ;-\mathrm{S}$.

153 BAS; ewyrth D.

$154 \mathrm{BAD} ;-\mathrm{S}$.

$155 \mathrm{BAD} ;-\mathrm{S}$.

156 A adds A.

157 BS; Gwyddien A; Twyddien D.

158 A; Euuael B; Enael D; Ennael S. S adds a Dobion a Dos, brodorion.

159 ADS; mibion B.

160 B; Dyfnwal AD; Dynynael S.

$161 \mathrm{~S}$ adds ap Edynyved ap Maxen Wledic.

162 BAD; - S.

163 BAD; Ddiriet S.

164 B; Gwyddien AD; Gwyddion S.

165 B; Dyfnwal AD; Dynynael S.

$166 \mathrm{BAD} ;-\mathrm{S}$.

167 BAS; a D.

168 Hengwrt 33 omitted §9.3.2. 
$[\$ 10.1]^{169}$ [19] Plant Don o Arfon: Gwydyon ${ }^{170} \mathrm{~m}$. Don, Gofannon ${ }^{171} \mathrm{~m}$. Don, Amaethon ${ }^{172}$ m. Don, Hunawg m. Don, Ydwal m. Don, Ienuydd ${ }^{173} \mathrm{~m}$. Don, Elestron ${ }^{174} \mathrm{~m}$. Don, Digant $^{175} \mathrm{~m}$. Don, Gylfaethwy ${ }^{176} \mathrm{~m}$. Don, Kymman ${ }^{177} \mathrm{~m}$. Don, Hed m. Don, Adyen ${ }^{178} \mathrm{~m}$. Don $^{179}$, Elawg ${ }^{180} \mathrm{~m}$. Don, Aryanrod ${ }^{181}$ ferch Don.

[\$10.2] Plant Math mab ${ }^{182}$ Mathonwy: Llew Llaw Gyffes ${ }^{183}$, Dylan ${ }^{184}$ Eil Tonn ${ }^{185}$, ${ }^{186}$ Blodeuwedd ${ }^{187}$ eu chwaer ${ }^{188}$, o ${ }^{189}$ Aryanrot $^{190}$ ferch Don ${ }^{191}$.

AUDYL A GANT ADAF VRÂS (Peniarth 102, pp. 11-12)

\section{[11] Awdl a gant Addaf Fras}

Cyfoethau'r drindod cyfoethau

cyfoethawg lluyssawg yr oelau

cyfarchwn canwn corn ddifiau

rhag llef corn Dofydd diamau

ergrynant rhac puchiant pechodau

gwadant hwy elyflu weithredau

[12] [...]eryddau

[...] o anoethau

[...] pryd barnau

caer yn glaer i'r glan eneidiau

mad ganer a gano i'r caerau

atfydd cur a meth kymell trethau

adfydd rhyfel dydd a dialau

adfydd draig Powys i gochwys grau

adfydd brain Gwynedd ynghydwleddau

adfydd Saeson taer gwedy tyrfau

[The riches of the Trinity, the riches,

opulent, numerous, of the holy oils,

Let us hail, let us play a horn on Thursday

before the certain sounding of the Lord's horn,

they will quake on account of desiring sins,

they, the vast multitude, will deny the deeds,

$[\ldots]^{192}$

$[\ldots]$ from wondrous things,

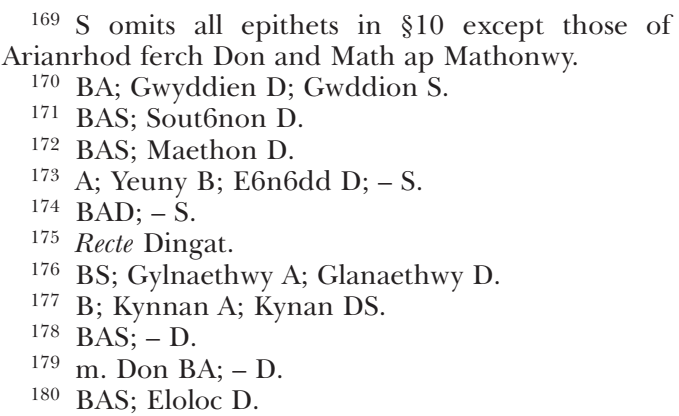

181 BA; Ariannoc D; Arianrawt S.

182 Math mab BAS; - D.

183 B adds m. Math.

184 BAD; $-\mathrm{S}$.

185 B adds m. Math.

$186 \mathrm{AD}$ add $\mathrm{a}$.

187 AD; Blodeufed B; Blotennedd S.

188 eu chwaer BAD; - S.

189 S adds chwaer.

190 BAS; Ariannoc D.

191 AS add eu mam.

192 David Callander suggests to me that [...]eryddau might be ceryddau, 'rebukes, chastisements'. 
$[\ldots]$ the time of judgements,

a fortress conspicuous to the clean souls,

he who sings for the fortresses sings well,

there will be pain and misfortune, the enforcement of dues,

there will be warfare, battle and vengeances,

there will be the dragon of Powys involved in bloody carnage,

there will be the ravens of Gwynedd in feasts together,

there will be the fierce English after tumults. ${ }^{193}$

ACH LLYWELYN AB IORWERTH DRWYNDWN (Cardiff Central Library 3.77, pp. 1-10)

[\$11.1] [1] Llwelyn mab Iorwerth ${ }^{194}$ mab Yweyn mab Gruffut m. Kynan m. Iago m. Idwal m. Meurig m. Idwal Foel m. Ana[2]rawt m. Rodri Mawr ${ }^{195} \mathrm{~m}$. Esyll ferch Gynan Dyndaethwy m. Rodri Malwynawg ${ }^{196} \mathrm{~m}$. Idwal Iwrch $\mathrm{m}$. Katwaladyr Vendygeyd $\mathrm{m}$. Katwallawn $^{197} \mathrm{~m}$. Katfan m. Iago m. Beli mab Run m. Maelgwn ${ }^{198}$ Gwyned m. Katwallawn ${ }^{199}$ Lawhir $^{200}$ m. Eynon ${ }^{201}$ Irth m. Kuneda Wledig m. Edern ${ }^{202}$ m. Padern ${ }^{203}$ Peisrud m. Tagyt ${ }^{204} \mathrm{~m}$. Iago m. Genedawg m. Kein m. Gorgein ${ }^{205} \mathrm{~m}$. Doli m. Gwrdoli m. Dwfyn m. Gordwfyn m. Amwerid ${ }^{206} \mathrm{~m}$. Onwet ${ }^{207} \mathrm{~m}$. Diuwg ${ }^{208} \mathrm{~m}$. Brychwein m. Yweyn m. Afallach m. Aflech m. Beli Mawr m. Manogan m. Eneid m. Kewyt m. Krydon m. Dyfnarch ${ }^{209} \mathrm{~m}$. Prydein m. Aed ${ }^{210}$ Mawr m. Antonius m. Seirioel m. Gwrwst m. Riwallawn m. Kuneda ${ }^{211} \mathrm{~m}$. Regau ${ }^{212}$ ferch Llyr ${ }^{213} \mathrm{~m}$. Bleidyd m. Run ${ }^{214}$ Baladr [3] Bras ${ }^{215} \mathrm{~m}$. Lleon $^{216} \mathrm{~m}$. Brutus Darian Las $^{217} \mathrm{~m}$. Efrawg $\mathrm{m}$. Mymbyr ${ }^{218} \mathrm{~m}$. Madawg m. Lokrinus $\mathrm{m}$. Bruttus twyssawg Rufein, y brenhin kyntaf a dyfu ${ }^{219}$ i'r ynys honn ${ }^{220}$, ag yn y bedwaredd oes o'r byd $d^{221}$ y dynu ${ }^{222} y_{m a}^{223}$. Bruttus m. Silfiws ${ }^{224} \mathrm{~m}$. Askanius ${ }^{225} \mathrm{~m}$. Eneas Yskwytwyn m. Enchises $^{226} \mathrm{~m}$. Kapis ${ }^{227}$ m. Assarakus m. $\operatorname{Tros}^{228}$ m. Eriktonius ${ }^{229}$ m. Dardanus ${ }^{230} a p^{231}$ Iupiter m. Sadwrn ${ }^{232}$ m. Silius ${ }^{233}$ m. Kretus m. Siprius m. Ketun ${ }^{234}$ m. Iauan ${ }^{235}$ m. Iaffeth
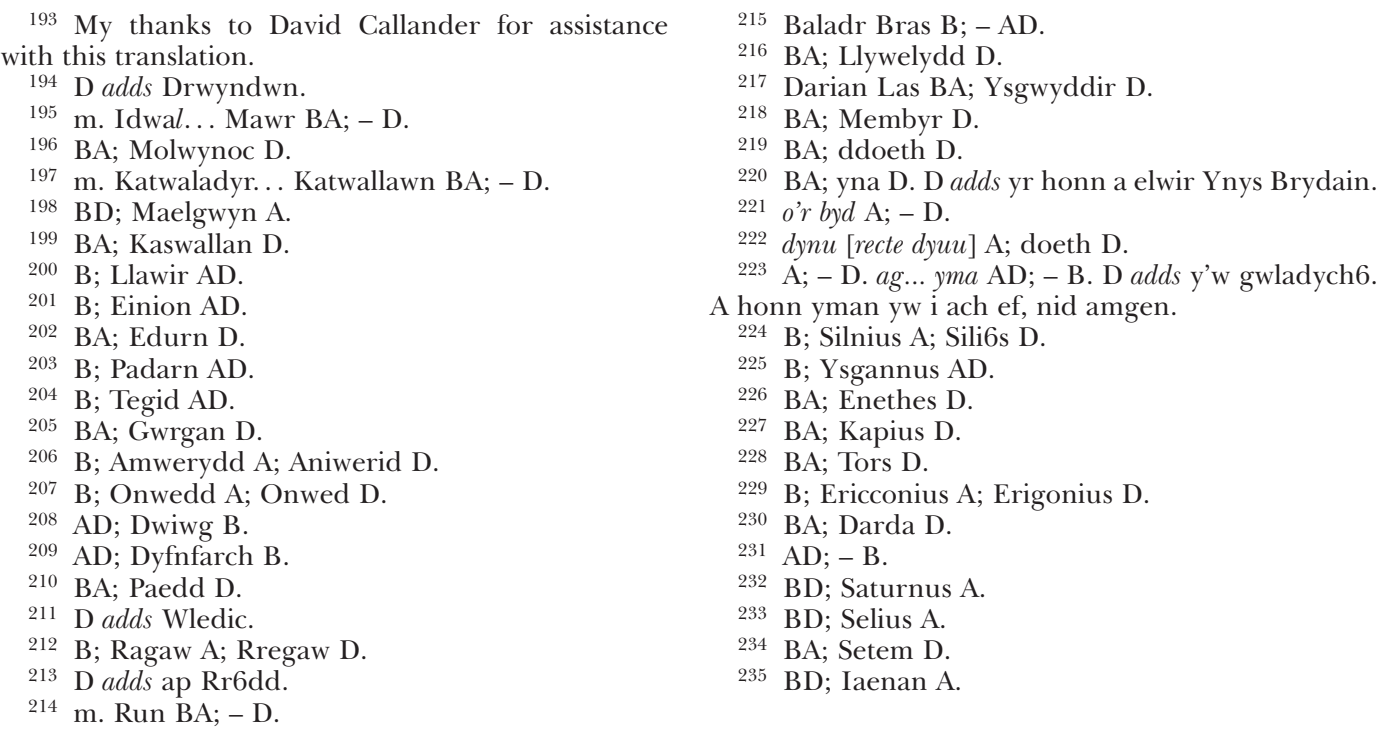
m. Noe Hen m. Lamech ${ }^{236}$ m. Matusale ${ }^{237}$ m. Enoc ${ }^{238}$ m. Iareth ${ }^{239}$ m. Malaleel ${ }^{240} \mathrm{~m}$. Kaynan mab Enos $^{241} \mathrm{~m}$. Seth mab Adaf ${ }^{242}$.

[\$11.1.1] Mam Llywelyn ${ }^{243}$ : Mareret ${ }^{244}$ ferch Madawg m. Moredyd ${ }^{245} \mathrm{~m}$. Bledin m. Kynfyn m. Gwerystan ${ }^{246} \mathrm{~m}$. Gweithfoet m. Gwrhidyr m. Kradawg ${ }^{247} \mathrm{~m}$. Lles Llawdeawg ${ }^{248}$ m. Ednifet m. Gwinnan m. Gwinnawg ${ }^{249} \operatorname{Varyf}^{S} \operatorname{Sech}^{250}$ [4] m. Keidaw ${ }^{251} \mathrm{~m}$. Korif ${ }^{252} \mathrm{~m}$. Kaenawg ${ }^{253} \mathrm{~m}$. Tegonwy $\mathrm{m}$. Teon $\mathrm{m}$. Gwineu Deu Vreudwyt $\mathrm{m}$. Bywyr ${ }^{254}$ Lew $\mathrm{m}$. Buwdeg $^{255} \mathrm{~m}$. Run Rud Baladyr m. Llary ${ }^{256}$ m. ${ }^{257}$ Kasnar $^{258}$ Wledig m. Llud m. Bely Mawr.

[\$11.1.2] Mam Fadawg ap Moredud ${ }^{259}$ oed $^{260}$ Hunyd ferch Einud m. Gwenlliant ferch Rys fab Marchan m. Kynwrig m. Kyndelw Gam m. Elgudy ${ }^{261} \mathrm{~m}$. Grwisnat ${ }^{262} \mathrm{~m}$. Dwywg Lyth $^{263} \mathrm{~m}$. Tegawg m. Dwyfnerch ${ }^{264} \mathrm{~m}$. Madog Madogiawn m. Sandef Bryt ${ }^{265}$ Egil m. $^{2}$ Llywarch Hen m. Elidir Lydanwyn m. Meirchiawn Gul m. Gwrwst Letlwm m. Keneu m. Koel Godebawg m. Tegfan m. Deheweint ${ }^{266} \mathrm{~m}$. Tudbwyll m. Vrban ${ }^{267} \mathrm{~m}$. Grad ${ }^{268} \mathrm{~m}$. Rifedel $^{269} \mathrm{~m}$. Rydeyrn ${ }^{270} \mathrm{~m}$. Endigant m. Endiyrnn m. Eneid ${ }^{271} \mathrm{~m}$. Endos m. Endoleu m. Afallach ap Aflech ${ }^{272}$ m. Beli Mawr.

[\$11.1.3 $]^{273}$ Mam Faredud mab Bledynt oed Huar ferch Vleidrud.

[\$11.1.4] [5] Mam Vledynt ap Kynfyn ${ }^{274}$ : Angharat ferch Faredud m. Yweyn m. Hywel Da m. Kadell Deyrnllug ${ }^{275}$ m. Rodri Mawr m. Merfin ${ }^{276}$ Vrich m. Gwryat m. Elidyr m. Sandef m. Alkwn ${ }^{277}$ m. Tagit ${ }^{278}$ mab $^{279}$ Gweir m. Dwg ${ }^{280}$ m. Llywarch Hen m. Elidir Lydanwyn.

[\$12] Plant Ywein Gwyned ${ }^{281}$ :

[\$12.1] Iorwerth ${ }^{282}$ a Maelgwn a Gwenlliant mam Wenwynwyn m. Yweyn Kyfeilyawg, plant ${ }^{283}$ Yweyn Gwyned, a ${ }^{284}$ Gwladus oed eu mam ${ }^{285}$, ferch Llywarch $\mathrm{m}$. Trahearn $\mathrm{m}$. Karadawg m. Gwynn m. Golwynn m. Ednywein m. Bledint m. Bletrus m. Kynawg Mawr m. Iorwerth Hirwlaut ${ }^{286} \mathrm{~m}$. Tegonwy m. Teon.

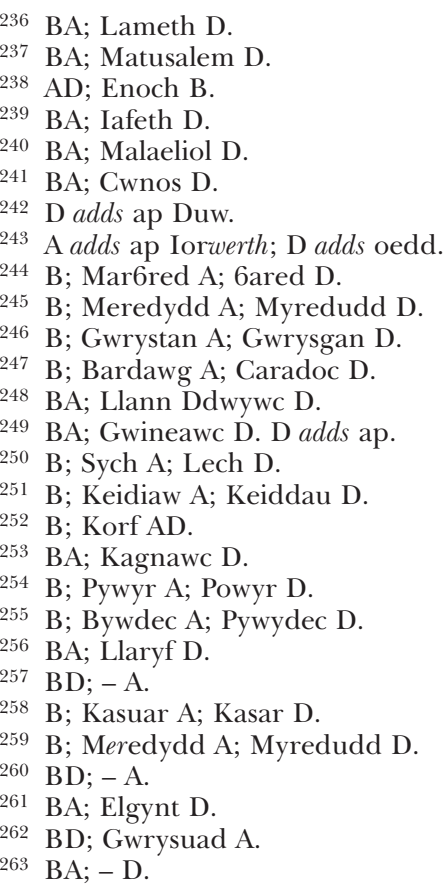

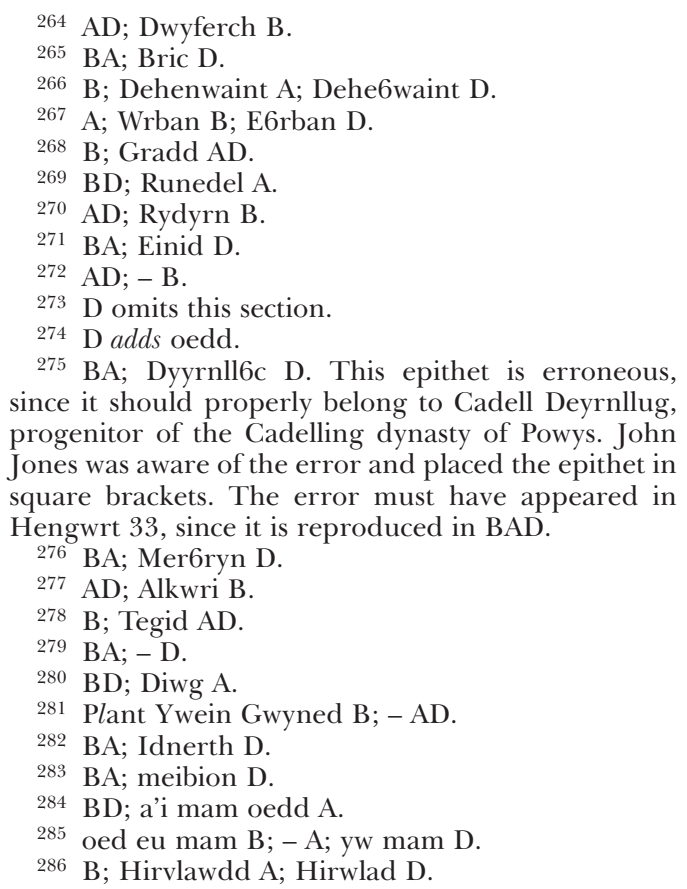
since it should properly belong to Cadell Deyrnllug, progenitor of the Cadelling dynasty of Powys. John Jones was aware of the error and placed the epithet in square brackets. The error must have appeared in Hengwrt 33, since it is reproduced in BAD.

276 BA; Mer6ryn D.

277 AD; Alkwri B.

278 B; Tegid AD.

279 BA; - D.

280 BD; Diwg A.

281 Plant Ywein Gwyned B; - AD.

282 BA; Idnerth D.

283 BA; meibion D.

284 BD; a'i mam oedd A.

285 oed eu mam B; - A; yw mam D.

286 B; Hirvlawdd A; Hirwlad D. 
[\$12.2] Dafyd a $a^{287}$ Rodri a Chatwallawn ${ }^{288}$ abat Enlly ag Angharat gwr[6]eig Gruffud Maelawr, meibyon ${ }^{289}$ Ywein Gwyned, a Christin ferch ${ }^{290}$ Ronw $^{291}$ m. Ywein m. Etwyn eu mam.

[\$12.2.1] Mam $^{292}$ Gristin $^{293}$ oed $^{294}$ Geneilles $^{295}$ ferch Hoedliw m. Ithael ${ }^{296} \mathrm{~m}$. Edrit ${ }^{297}$ mab $^{2}$ Inethan ${ }^{298} \mathrm{~m}$. Iasseth ${ }^{299} \mathrm{~m}$. Karwet m. Marchud.

[\$12.2.2] Mam Oronwy ${ }^{300} \mathrm{~m}$. Ywein ${ }^{301}$ : Morwyl ${ }^{302}$ ferch Etnywein Pentew m. Nemiad ${ }^{303} \mathrm{~m}$. Gweithfoet m. Gwridir.

[\$12.2.3] Mam Ywein ap Etwyn ${ }^{304}$ : Iweryd ${ }^{305}$ ferch Gynfyn m. Gweristan.

[\$12.2.4] Mam Iweryd ${ }^{306}$ : Angharat ferch Faredud m. Ywein m. Hywel Da m. Kadell m. Rodri Mawr.

[\$12.3] Kynan m. Ywein: Angharat oed y fam, ferc Peredur m. Mael m. Bledynt o Feirionyd.

[\$12.4] Llywelyn m. Yweyn ${ }^{307}$ : Gwenllyant ${ }^{308}$ [7] ferch Etnywein m. Gwrydyr ${ }^{309} \mathrm{~m}$. Dyfneint oed y fam ${ }^{310}$.

[\$12.5] $]^{311}$ Meredydd Ddu ap Owain: Morvydd verch Gerwydd Hir i Gam.

[\$12.6] Idwal m. Yweyn: Afandreg ferch Wrgi o Penn Mynyd Gradifel y fam.

[\$12.7] Run m. Yweyn: Aned ferch Wrgi y fam ${ }^{312}$, chwaer $^{313}$ Afandreg.

$[\$ 12.9]^{314}{ }^{315}$ Hywel $^{316} \mathrm{~m}$. Yweyn ${ }^{317}$ : Ffynnot Wydeles oed y fam.

[\$12.10] Deu Gynwrig a vuant ${ }^{318}$ feibyon y Yweyn.

[\$12.10.1] Un o nadunt a wyst $l$ ws $^{319}$ Ywein y Henri vrenhin ${ }^{320}$ yg Koet Keiryawg, ag y dallwyt ${ }^{321} \mathrm{y}^{322}$ gyt a'r gwystlon pann dorres Yweyn; ag o hynny y bu farw ${ }^{323}$.

[\$12.10.2] Y Kynwrig arall a elwyt Kynwryg fab y faerones ${ }^{324}$.

[\$12.11] Ffylip m. Ywein: Morfud ferch Elfan ${ }^{325} \mathrm{~m}$. Sandef o $\operatorname{Ros}^{326}$ y fam.

[\$12.12] Ririd ${ }^{327} \mathrm{~m}$. Ywein, e gwr bieuvu ${ }^{328}$ Glochran, y dref a rodet ${ }^{329}$ y hen [8] Ruffud m. Kynan ${ }^{330}$, yssyd y ${ }^{331}$ rwng Dinas ${ }^{332}$ Dulyn a Swrth ${ }^{333}$ Kolomkilli $^{334}$.

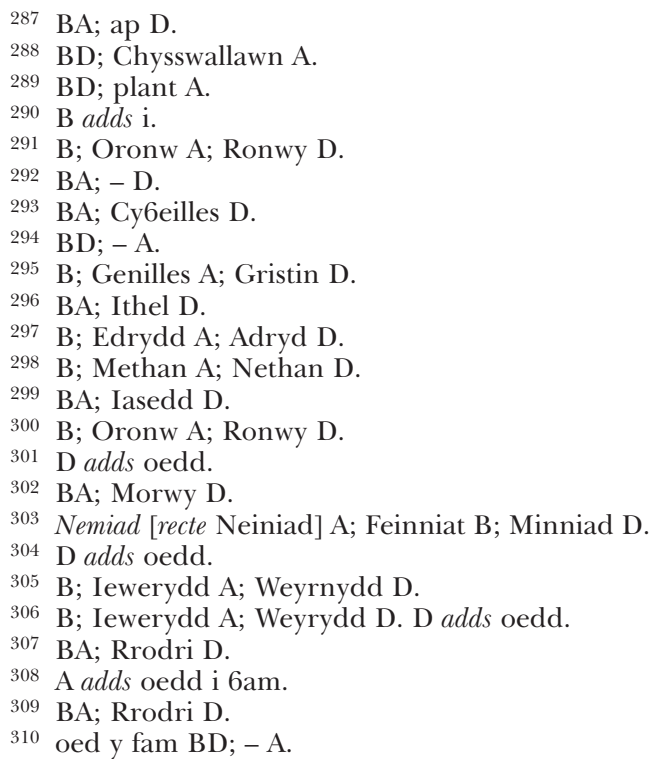

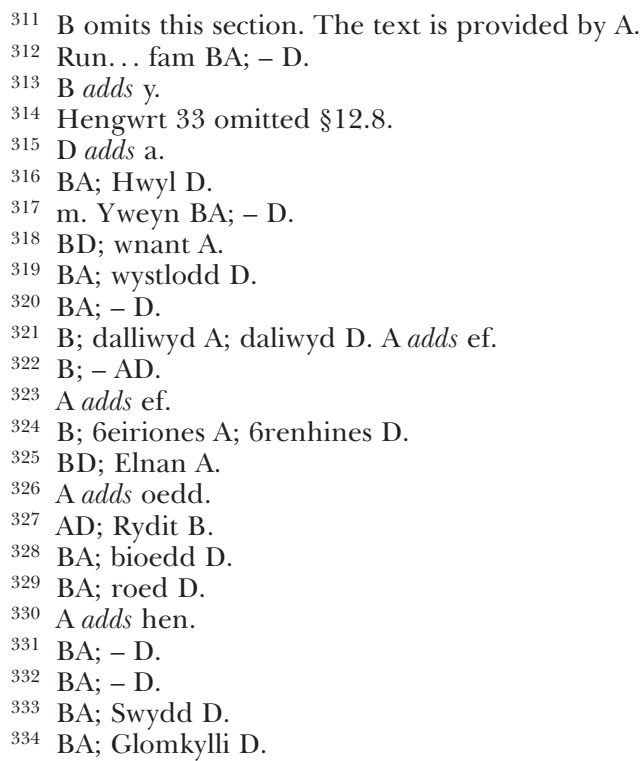


[\$27] En $^{335}$ tri lle y dylyit ${ }^{336} \operatorname{arglwydiaeth}$ Wyned o gogeil ${ }^{337}$ :

[\$27.1] Un o nadunt ${ }^{338}$ : Stratweul ${ }^{339}$ ferch Gadeann ${ }^{340} \mathrm{~m}$. Kynan m. Eudaf m. Karadawg m. Bran m. Llyr Lledyeyth, gwreig y Goel Godebog ${ }^{341}$ oed $^{342}$, mam Dyfyrwr ${ }^{343}$, a mam ${ }^{344}$ Geneu fab Koel.

[\$27.2] Ei $l^{345} \mathrm{yw}^{346}$ Gwawl ferch Koel Godebawg, mam Guneda Wledig, gwraig Edern ${ }^{347}$ m. Padern ${ }^{348}$ Peysrud.

[\$27.3 ${ }^{349}$ Trydyd $^{350} \mathrm{yw}^{351}$ Esil ferch Gynan Dyndaethwy, gwreig Ferfyn ${ }^{352}$ Vrich, mam Rodri Mawr.

$[\S A 4]^{353}$ Llyma ach Ednyfet Vychan ${ }^{354}$ :

[\$A4.1] [9] Ednyfet Vychan m. Kynwrig m. Iorwerth m. Gwgawn m. Idnerth m. Edryd m. Inethan $^{355} \mathrm{~m}$. Iassed ${ }^{356} \mathrm{~m}$. Karwet $\mathrm{m}$. Marchud $\mathrm{m}$. Kynan $\mathrm{m}$. Elyfyw ${ }^{357} \mathrm{~m}$. Mor m. Mynan m. Yspwys m. ${ }^{358}$ Mwyntyrch m. Yspwys m. Kadrawt Kalchfynyd m. Kynwyt Kynwydyawn m. Kynfelyn m. Mar ${ }^{359}$ m. Keneu m. Koel Godebawg.

[§A4.1.1] Mam Ednyfet ${ }^{360}$ : Angharad ferch Hwfa m. Kynwrig m. Riwallawn m. Dingat m. Dudur $\mathrm{m}$. Ymyr ${ }^{361} \mathrm{~m}$. Kadfarch $\mathrm{m}$. Gwernnen $\mathrm{m}$. Gwaedgar ${ }^{362} \mathrm{~m}$. Bywyn ${ }^{363} \mathrm{~m}$. Byorderch ${ }^{364} \mathrm{~m}$. Gwylawr m. Gwynan ${ }^{365} \mathrm{~m}$. Kadell Deyrnllug ${ }^{366} \mathrm{~m}$. Pasken m. Brydw ${ }^{367} \mathrm{~m}$. Rydfede $l^{368}$ Vrych m. Kadeyrn m. Gwrtheyrn ${ }^{369}$ Gortheneu m. ${ }^{370}$ Rydeyrn m. Deheweint ${ }^{371}$ m. Endigant m. Endeyrn m. Eneid ${ }^{372}$ m. [10] Endos m. Endoleu m. A6allach ${ }^{373} \mathrm{~m}$. Aflech m. Beli Mawr.

CHRONICL BYRR YN DECHREU YN OES ARTHUR, PAN LAS ARTHUR (Cwrtmawr 453, pp. 27-31)

[27] Oyd yr Arglwyd pan las Arthur yg ${ }^{374}$ gad Gamlan: pim cant a deugeint mlined ${ }^{375}$ oed y oyd ${ }^{376}$.

35 B; - A; Mewnn D.

336 B; dyleid A; delir A.

337 BA; gogeile D.

338 A adds yw; D adds oedd.

339 BA; Ystradwel D.

340 BA; Gad6an D.

341 A adds hon.

$342 \mathrm{BA} ;-\mathrm{D}$.

343 BA; Ddyfr D.

$344 \mathrm{BA} ;-\mathrm{D}$.

$345 \mathrm{D}$ adds lle.

346 BA; - D.

347 B; Edyrn AD.

348 B; Padarn AD.

349 AD add $\mathrm{Y}$.

$350 \mathrm{D}$ adds lle.

351 B; oedd A; - D.

352 BA; 6er6ryn D.

353 As is explained in my forthcoming edition of the archetypal text of the Llywelyn ab Iorwerth genealogies, sections beginning with 'A' were probably not part of the original text, but were probably added at an early stage in the textual tradition.

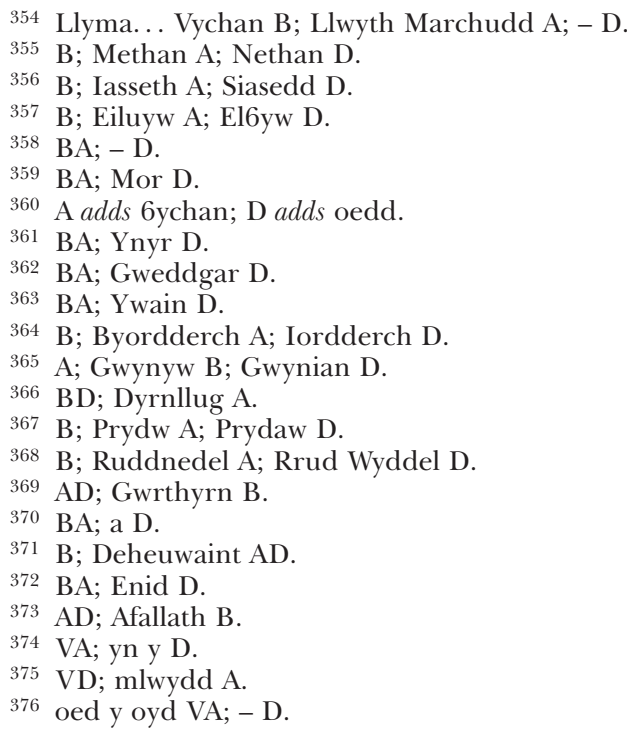


${ }^{377}$ Oyd yr Arglwyd pan haeth Cadwaladyr Vendigeit ${ }^{378}$ i Ruuein: 653.

${ }^{379}$ Oyd er Arglwyd pan vw Offha ${ }^{380}$ vrenhyn $^{381}$ : seith cant ag vn vlwidyn a phedwar ugeint.

${ }^{382}$ Pan wu varw Llywelyn ap ${ }^{383}$ Ioruerth, ${ }^{384}$ eil $\mathrm{dyd}^{385}$ o Ebrill: mil a deucant a deugein oyd oed [28] $y^{386}$ Arglwid $^{387}$.

Oyd yr Arglwyd pan doyd Normannieit ${ }^{388} i^{\prime} r^{389}$ ynys hon: mlxvi.

${ }^{390}$ Oyd yr Arglwyd pan wneithbwit ${ }^{391}$ Sistos: mcxxvi.

Oyd yr Arglwyd pan las Thomas archescop Kaint ${ }^{392}$ : mclxxi ${ }^{393}$.

Oyd yr Arglwyd pan fu varw Madauc ap Gruffid Maelawr: mccxxxv ${ }^{394}$.

${ }^{395}$ Oyd yr Arglwyd pan gad castell Carreckoua: mccxlviii ${ }^{396}$. Ag y bu vroydir yny Cymereu y uloydin honno.

${ }^{397}$ Oyd yr Arglwyd pan [29] gad castell Carrecphaelan: mccxli.

Oyd yr Arglwyd pan vv uarw Gruffid ap Llewelyn: mccxliiii ${ }^{398}$.

Oyd yr Arglwyd pan vv ${ }^{399}$ uarw Dauid ap Llewelin iiii kalendas Marcias ${ }^{400}$ : mccxlvi.

Oyd yr Arglwyd pan grynaud y dayar: x kalendas Marcias ${ }^{401}$ : mccxlvii.

Oyd yr Arglwyd pan dorrad castell Maishyueid ${ }^{402}$, wedi gwyl saint Freid ${ }^{403}$ : mcclxiii $^{404}$. Ac y cad castell e Diserth Aust ${ }^{405}$, ac y gad ${ }^{406}$ castell Dyganwy ygwyl ${ }^{407}$ Vihangel $^{408}$.
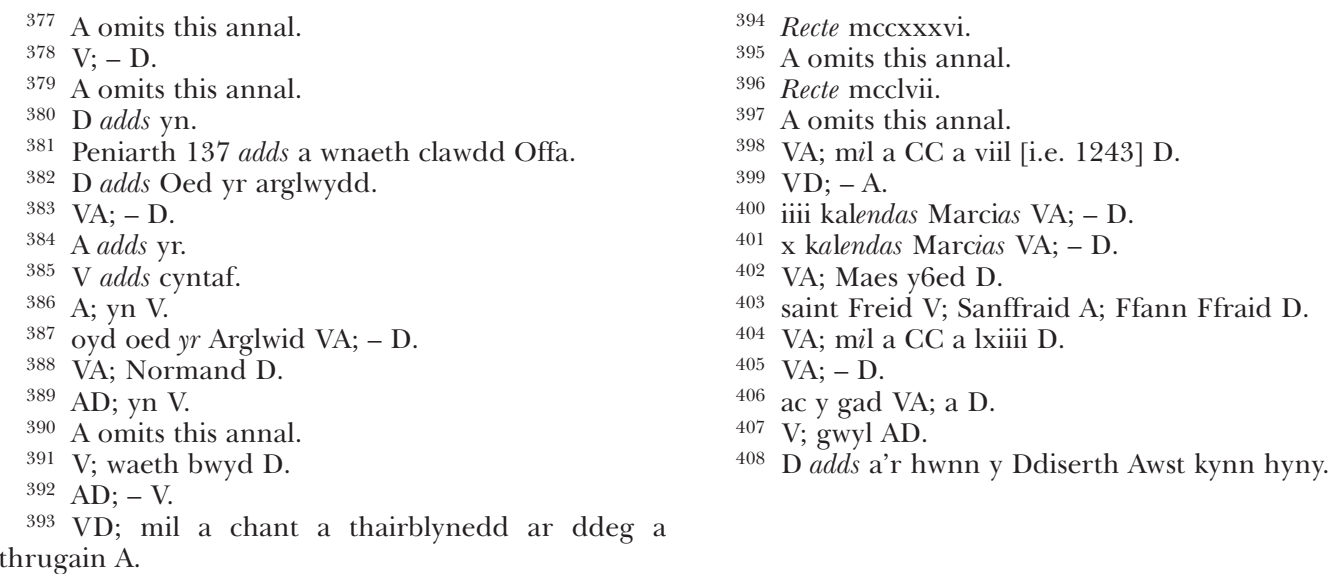
[30] Oyd yr Arglwyd pan las Simownd iii kalendas Augustias ${ }^{409}$ : mcclxv. Ac y distrywt ${ }^{410}$ castell Penhardalauc vi kalendas Obtobras ${ }^{411}$ yn y flwydyn hono ${ }^{412}$.

Oyd yr Arglwyd pan vv uarw Hywel ap ${ }^{413}$ Madauc: mcclxviii.

Oyd yr Arglwyd pan gad Caerfili iiii id $u s^{414}$ Octobras $^{415}$ : $\operatorname{mcclxix}^{416}$.

Oyd yr Arglwyd pan vv uarw Iewan yarll Warant ${ }^{417}$ : mccciiii $^{418}$.

Oyd yr Arglwyd pan fu farw Edward ureyenyn Lloe[31]gyr: mcccvii. A'r ${ }^{419}$ nawuet dyd o Iuliii $^{420}{ }^{421} \mathrm{yn}$ yr vn ${ }^{422}$ vlydyn y gwisgywt ${ }^{423}$ goron e dyurnas am ben Edward y vab.

[The age of the Lord when Arthur was killed in the battle of Camlan: five hundred and forty years was his age.

The age of the Lord when Cadwaladr Vendigaid went to Rome: 653.

The age of the Lord when Offa was king: seven hundred and eighty-one years.

When Llywelyn ab Iorwerth died, on the second day of April: one thousand, two hundred and forty was the age of the Lord.

The age of the Lord when the Normans came to this island: 1066.

The age of the Lord was the Cistercians were founded: 1126.

The age of the Lord when Thomas, archbishop of Canterbury, was killed: 1171.

The age of the Lord when Madog ap Gruffudd Maelor died: $1235^{424}$.

The age of the Lord when Carreghofa castle was taken: $1247^{425}$. And in that year there was a battle in Cymerau.

The age of the Lord when Carreg Faelan [Diserth] castle was taken: 1241.

The age of the Lord when Gruffudd ap Llywelyn died: 1244.

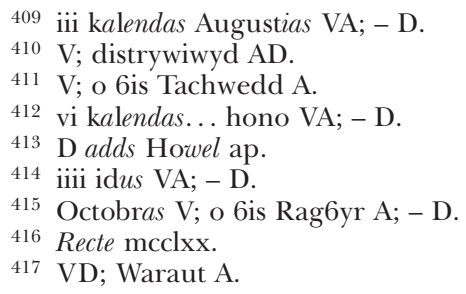

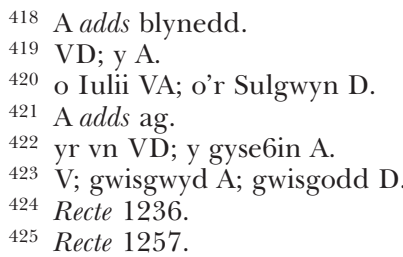

418 A adds blynedd.

420 o Iulii VA; o'r Sulgwyn D.

421 A adds ag.

422 yr vn VD; y gyse6in A

424 Recte 1236.

425 Recte 1257. 
The age of the Lord when Dafydd ap Llywelyn died on the 4th day from the kalends of March: 1246.

The age of the Lord when the earth shook on the 10th day from the kalends of March: 1247.

The age of the Lord when Maesyfed [New Radnor] castle was broken, after the festival of St Brigit: 1263. And Diserth castle was taken in August, and Degannwy castle was taken on the festival of Michael.

The age of the Lord when Simon was killed on the 3rd day from the kalends of August: 1265. And Penarlâg [Hawarden] castle was destroyed on the 6th day from the kalends of October in that year.

The age of the Lord when Hywel ap Madog died: 1268.

The age of the Lord when Caerphilly castle was taken on the fourth day from the ides of October: $1269^{426}$.

The age of the Lord when John Earl Warenne died: 1304.

The age of the Lord when Edward, king of England, died: 1307. And on the ninth day of July in the same year the crown of the kingdom was worn around the head of Edward his son.]

\section{ENWAU BRENHINOEDD YNYS PRYDAIN (Cwrtmawr 453, pp. 33-8)}

[33] Henwe y Brenhyned ${ }^{427}$ :

Eneas ysgwythwyn ${ }^{428}$, gwedy yntau Ascanus, gwedy ynteu Silius, gwedy ynteu Brutus ${ }^{429}$, gwedy ynteu Locrinus ${ }^{430}$, gwedy ynteu Madauc, gwedy ynteu Membyr ${ }^{431}$, gwedy ynteu Efrawc, gwedy ynteu Brutus Darian Las, gwedy ynteu Lleon, gwedy ynteu Run, gwedy ynteu Bleidud, gwedy ynteu Llyr, gwedy ynteu Cordoilla ${ }^{432}$, gwedy honno Cuneda, gwedy ynteu [34] Riwallawn, gwedy ynteu Gwrwst, gwedy ynteu Seissill, gwedy ynteu Iago, gwedy ynteu Cynvarch, gwedy ynteu Gwrvyw, gwedy ynteu Porrex, gwedy ynteu Dyfynwal Moel Müt, gwedy ynteu Beli, gwedy ynteu Gwrgant Varfdrwch ${ }^{433}$, gwedy ynteu Cuelyn ${ }^{434}$, gwedy ynteu Seissill, gwedy ynteu Cynvarch, gwedy ynteu Danvyw, gwedy ynteu Morud, gwedy ynteu Gwrvyw, gwedy ynteu Arthal, gwedy ynteu Ywein, gwedy ynteu Peredur, gwedy ynteu Elidir, [35] gwedy ynteu Rys, gwedy ynteu Margan ${ }^{435}$, gwedy ynteu Einyawn, gwedy ynteu Idwal, gwedy ynteu Run, gwedy ynteu Gereint, gwedy

426 Recte 1270.

427 Henwe y Brenhyned V; Henway brenhinoed Ynys Brydaen o distrywedigaeth Toea i distrywedigaet Ynys Prydaen B; Henwa6 y brenhinedd o'r Bryttanieid A; Llyma henwa6 brenhinoedd Kymry kynn kael o'r Saesonn veddiant ar y dyrnnas D.

428 V; Ysgwydwyn B; Ysgwyddwynn D.

429 Eneas... Brutus VBD; Brutus ap Siluius 6u'r kyntaf A.
430 ABD; Locnus V.

431 VB; Mymbyr A; Embyr D.

432 VBA; Kordilla D.

433 BA; Varfdwrch V.

434 VB; Kuhelyn A.

435 VB; Morgant A. 
ynteu Cadell, gwedy ynteu Coel, gwedy ynteu Porrex, gwedy ynteu Eidol, gwedy ynteu Auarwy, gwedy ynteu Vrien, gwedy ynteu Eluyd, gwedy ynteu Cludawg ${ }^{436}$, gwedy ynteu Gwrwst ${ }^{437}$, gwedy ynteu Meiryawn, gwedy ynteu Bleidud, gwedy ynteu Caph ${ }^{438}$, gwedy ynteu Ywein, gwedy ynteu Seissillt, gwedy ynteu Blegywryt ${ }^{439}$, gwedy ynteu Arthmael ${ }^{440}$, [36] gwedy ynteu Eidol, gwedy ynteu Ryderch, gwedy ynteu Sawyl, gwedy ynteu Pyrr, gwedy ynteu Pab ${ }^{441}$, gwedy ynteu Mynogan, gwedy ynteu Beli Mawr, gwedy ynteu Llud, gwedy ynteu Caswallawn ${ }^{442}$, gwedy ynteu Tenefan ${ }^{443}$, gwedy ynteu Cynvelyn, gwedy ynteu Gwydyr, gwedy ynteu Gweirydd ${ }^{444}$ Adarweinidawc ${ }^{445}$, gwedy ynteu Meuric, gwedy ynteu Coel, gwedy ynteu Lles, gwedy ynteu Seuerus, gwedy ynteu Basianus, gwedy ynteu Carawn, gwedy ynteu Alectus ${ }^{446}$, [37] gwedy ynteu Ascla, gwedy ynteu Coel, gwedy ynteu Constans, gwedy ynteu Custennin, gwedy ynteu Trahayarn, gwedy ynteu Eudaf, gwedy ynteu Maxen, gwedy ynteu Gratian $\mathbf{n}^{447}$, gwedy ynteu Custennin, gwedy ynteu Constans, gwedy ynteu Gorthyyrn ${ }^{448}$ Gortheneu $^{449}$, gwedy ynteu Gwerthyuyr ${ }^{450}$, gwedy ynteu Emreis ${ }^{451}$, gwedy ynteu Vthyr Bendragon, gwedy ynteu Arthur, gwedy ynteu Custennin, gwedy ynteu Kynan ${ }^{452}$, gwedy ynteu Mortiporus ${ }^{453}$, gwedy ynteu Maelgwn ${ }^{454}$, gwedy ynteu Ceredic, gwedy ynteu Einiawn ${ }^{455}$ [38] gwedy ynteu Beli, gwedy ynteu Iago, gwedy ynteu Catvan, gwedy ynteu Cadwallawn, gwedy ynteu Catwaladyr Vendigeit.

$436 \mathrm{~V}$; Klydawg BA.

437 BA; Gwrwic V.

438 VA; Kath B.

439 B; Blegwryt V; Blegerwyd A.

440 VB; Arthavael A.

441 VB; Pabyr A. In V a $v$ has been expuncted at the end of this word.

442 VBD; Cadwallawn A.

443 B; Tynnvan V; Tynevan A; Tynn6a[...] D.

444 VBA; Gweuydd D.

${ }_{445} \mathrm{VBA}$; Ada wenydawc D. In V this word is underlined and arwyneddog is written in the left-hand margin.
446 VBA; Alactus D.

447 V; Grasian B; Gracian A; Gradian D.

448 VB; Gwrtheyrn A; Gwreyrn D.

449 VB; - A; Gwrthena6 D.

450 VD; Gwerthefur B; Gwrtheuyr A. A adds

Vendigaid.

451 VBA; Emrys D.

452 BAD; - V.

453 V; Mortiporws B; Moreporys A; Morti[...] D. An error in Hengwrt 33 for Vortiporus.

454 VB; Maelgwyn A. A adds Gwynedd.

455 B; Enuawn V; Einawn A. 